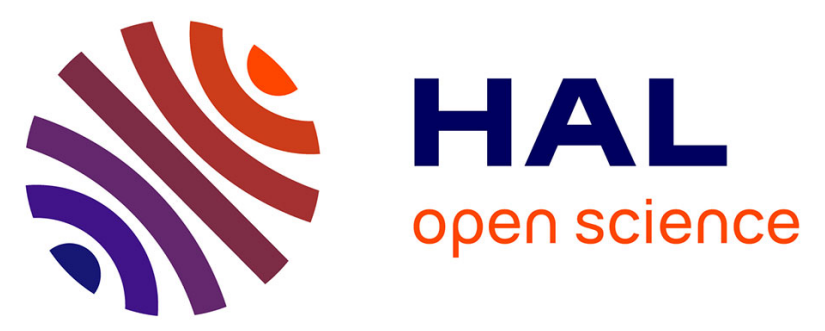

\title{
The Roussillon Basin (S. France): A case-study to distinguish local and regional events between 6 and $3 \mathrm{Ma}$
}

Georges Clauzon, Paul Le Strat, Cédric Duvail, Damien Do Couto, Jean-Pierre Suc, Stéphane Molliex, François Bache, David Besson, Everett H. Lindsay, Neil D. Opdyke, et al.

\section{To cite this version:}

Georges Clauzon, Paul Le Strat, Cédric Duvail, Damien Do Couto, Jean-Pierre Suc, et al.. The Roussillon Basin (S. France): A case-study to distinguish local and regional events between 6 and 3 Ma. Marine and Petroleum Geology, 2015, 66, pp.18-40. 10.1016/j.marpetgeo.2015.03.012 . hal01254424

\section{HAL Id: hal-01254424 https://hal.science/hal-01254424}

Submitted on 12 Jan 2016

HAL is a multi-disciplinary open access archive for the deposit and dissemination of scientific research documents, whether they are published or not. The documents may come from teaching and research institutions in France or abroad, or from public or private research centers.
L'archive ouverte pluridisciplinaire HAL, est destinée au dépôt et à la diffusion de documents scientifiques de niveau recherche, publiés ou non, émanant des établissements d'enseignement et de recherche français ou étrangers, des laboratoires publics ou privés. 


\title{
The Roussillon Basin (S. France): a case-study to distinguish local and regional events between 6 and 3 Ma
}

\author{
Georges Clauzon $^{1^{*}}$, Paul Le Strat ${ }^{2}$, Cédric Duvail ${ }^{3}$, Damien Do Couto ${ }^{4}$, \\ Jean-Pierre Suc ${ }^{5-6}$, Stéphane Molliex ${ }^{7}$, François Bache ${ }^{8}$, David Besson', \\ Everett H. Lindsay ${ }^{10}$, Neil D. Opdyke ${ }^{11}$, Jean-Loup Rubino ${ }^{12}$, Speranta-Maria \\ Popescu $^{13}$, Bilal U. Haq ${ }^{5-6,14}$, Christian Gorini ${ }^{5-6}$
}

1, Aix-Marseille Université, CNRS, IRD, CEREGE UM34, 13545, Aix-enProvence, France

* G. Clauzon died on March, 12, 2013

2, 19 chemin du Champ Juvénal, 34170 Castelnau-le-Lez, France

3, GEOTER SAS, FUGRO Group, 3 rue Jean Monnet, 34830 Clapiers, France

4, Section of Earth and Environmental Sciences, University of Geneva, 13 rue des Maraîchers, CH-1205, Geneva, Switzerland

5, Sorbonne Universités, UPMC Univ. Paris 06, UMR 7193, Institut des Sciences de la Terre Paris (iSTeP), 75005 Paris, France

6, CNRS, UMR 7193, Institut des Sciences de la Terre Paris (iSTeP), 75005 Paris, France

7, Université de Bretagne Occidentale, IUEM, Domaines océaniques, UMR 6538 CNRS, 1 place Nicolas Copernic, 29280 Plouzané, France

8, GNS Science, Ocean Exploration Section, P.O. BOX 30368, Lower Hutt 5040, New Zealand

9, DREAL Centre, SHPEC/DHMD, 5 avenue Buffon, 45064 Orléans La Source, Cedex 2, France

10, Department of Geosciences, Building \#77, University of Arizona, Tucson, AZ 85721, USA

11, Department of Geology, University of Florida, Gainesville, FL 32611, USA

12, TOTAL, TG/ISS, CSTJF, Avenue Laribeau, 64018 Pau Cedex, France

13, GeoBioStratData.Consulting, 385 route du Mas Rillier, 69140 Rillieux la Pape, France

14, National Science Foundation, Washington, DC, USA

*Corresponding author: Jean-Pierre Suc, jeanpierre.suc@gmail.com

\begin{abstract}
The Roussillon Basin is a non-silled Miocene sedimentary basin filling a late Oligocene-early Miocene graben. The basin was intensively impacted by the
\end{abstract}


Messinian fluvial erosion, as evidenced in exposed sections, in seismic profiles and in deep boreholes drilled for hydrocarbon exploration. As the basin was open to the Mediterranean Sea, the huge drop in sea level at the peak of the Messinian Salinity Crisis is clearly recorded, along with the subsequent sudden marine reflooding and the resulting prograding sedimentary filling, particularly in Gilbert-type fan deltas. Here, the Messinian Erosional Surface (MES) is accurately mapped in a high-resolution document, which corrects the confusion resulting from the set of 1:50,000 scale regional maps. Aim of the 3D reconstruction of the MES is to modernize geological mapping, a crucial challenge for Mediterranean and peripheral areas. Thanks to a reliable chronostratigraphy provided by planktonic foraminifers, calcareous nannofossils, micro- and macro-mammal remains, paleomagnetism and a ${ }^{10} \mathrm{Be}$ cosmogenic nuclide-derived study, our reconstruction is one of the most comprehensive models of changes in sea level from 6 to $3 \mathrm{Ma}$. After the marine reflooding of the Mediterranean Basin at $5.46 \mathrm{Ma}$, the fluctuations in sea level recorded in the Roussillon Basin were forced by global changes. Following reflooding, the Prades large olistostrome collapsed prepared by the previous exhumation along the Canigou fault. The olistostrome is a good example of a local accident resulting from Messinian events. The exceptional changes in sea level at the peak of the Messinian Salinity Crisis deeply marked the Roussillon Basin, momentarily overprinting the Pyrenean orogenesis.

Key words: Roussillon Basin - Messinian subaerial erosion -Zanclean sedimentary filling -Prades olistostrome.

\section{Introduction}

The Roussillon Basin (southern France; Fig. 1A) opened as a consequence of the Corsica-Sardinia rifting that created the Algiers-Provence Basin in the Late Oligocene - Early Miocene (Guennoc et al., 1994; Mauffret et al., 2001). Thanks to long-term onshore and offshore investigations, this basin is one of the best known Neogene areas in the Mediterranean region (Depéret, 1885, 1890-97; Bourcart, 1945; Gottis, 1958; Baudelot and Crouzel, 1974; Cravatte et al., 1974, 1984; Michaux, 1976; Suc, 1976; Cravatte and Suc, 1981; Mein and Aymar, 1984; Clauzon and Cravatte, 1985; Clauzon, 1987, 1990; Clauzon et al., 1987, 1990; Aguilar et al., 1999; Guennoc et al., 2000; Duvail et al., 2005; Aunay et al., 2006; Suc and Fauquette, 2012). The structure of the Roussillon Basin was acquired during the Tortonian via two major faults (Albères and Prades) (Fig. 1B), which control its contact with the Hercynian metamorphic basement (Clauzon, 1987; Mauffret et al., 2001; Le Strat and Duvail, 2008). The modern west-east fluvial drainage was also established at that time and was already down-cut in response to the uplift of the Canigou Massif (Clauzon, 1987).

Because the Roussillon Basin remained open during the Messinian drawdown, (1) the peripheral evaporites ( $1^{\text {st }}$ step of the Messinian Salinity Crisis: MSC; Clauzon et al., 1996) were not deposited here, and (2) the Messinian down-cutting of the preexisting fluvial network ( $2^{\text {nd }}$ step of the MSC; Clauzon et al., 1996) had a significant impact on the basin (Clauzon et al., 1990; Duvail et al., 2005). As a result, the older Neogene deposits almost completely disappeared from the basin, which, in contrast, contains records of the marine reflooding and Zanclean variations in sea level (Fig. 1B). The vast overlay of continental Quaternary deposits makes it difficult to observe the contact between Zanclean deposits and older rocks (i.e. the Messinian Erosional Surface, MES) except for the proximal river valleys, the edges of the basin and three 
more or less distal wells (Ponteilla, Canet 1 and Elne 1). Geological mapping is thus needed to accurately locate the MES and its onshore to offshore course.

This paper (1) presents an up-to-date summary of the Roussillon Basin made possible by the completion of maps, which enabled us to correct some recently published maps, (2) improves the three-dimensional representation of the MES, and (3) shows the sedimentary response to minor variations in Zanclean sea level. This paper is a major contribution to the new 3D evolutive mapping project of the French Geological Survey (B.R.G.M.) named the French Geological Reference Platform. After characterizing the MES offshore and onshore and recalling its dating, (1) we provide an interpolated three-dimensional onland map that correlates with the offshore map published by Guennoc et al. (2000) and Gorini et al. (2005), (2) we pay particular attention to Zanclean variations in sea level, and (3) describe an outstanding local olistostrome, and discuss its possible links with events caused by the MSC.

\section{The Messinian Erosional Surface}

The MES is well studied offshore from the Gulf of Lions (Gorini, 1994; Guennoc et al., 2000; Lofi et al., 2003, 2005, 2011; Bache et al., 2009) where Miocene sediments (below the unconformity) and Pliocene sediments (above the unconformity) were accurately dated by foraminifer biostratigraphy in several long boreholes (Cravatte et al., 1974). The corresponding stratigraphic gap was evidenced onshore in the Canet 1 and Elne 1 wells (Fig. 1B) (Cravatte et al., 1984; Clauzon and Cravatte, 1985). Landward, in many places in the Roussillon Basin, evidence of the MES has been found in either the basement or continental Miocene deposits, with reliable ages provided by mammals (Depéret, 1890-97; Guérin, 1975, 1982; Clauzon et al., 1987), calcareous nannofossils (Cravatte et al., 1984) or mollusks (Fontannes, 1879-82; Depéret, 1890-97; Martinell and Doménech, 1984, 1990).

Here, we present unpublished and partially published data consisting in (1) two offshore seismic profiles (one crossing the Tramontane 1 well), (2) three long onshore transects using available well logs, and (3) proximal evidence of the MES. This approach resulted in a new geological map of the Roussillon Basin and in a 3dimensional reconstruction of the MES.

\subsection{Offshore seismic profiles}

The seismic lines LRM96-08 and LRM96-11 (Fig. 1B), acquired in 1996 by the ElfAquitaine Company, show the MES characterized by erosional truncations of underlying strata and downlap termination of seismic reflectors of overlying strata (Figs. 2 and 3). Boreholes show that the erosion surface truncates sediments of the Miocene age and is covered by sediments of the earliest stage of the Pliocene (Cravatte et al., 1974). In Rascasse 1 well (Chevron Oil Company, 1979; Fig. 1B), a sedimentary gap has been described at the top of the Miocene sequence at a depth of 1814 m (Guennoc et al., 2000; Gorini et al., 2005; Lofi et al., 2011). The youngest Miocene sediments were found in the Tramontane 1 well and were dated as Tortonian (Fig. 3; Cravatte et al., 1974). In this well, the base of the Pliocene sequence was identified at a depth of $875 \mathrm{~m}$ (i.e. $865.5 \mathrm{~m} \mathrm{bsl}$ ) at the beginning of the continuous occurrence of the planktonic foraminifer Globorotalia margaritae (Cravatte et al., 1974). Up to 7 Myrs of the Upper Miocene sediment record are missing in the Autan 1 borehole at the shelf edge, where the youngest deposits are dated $\sim 12 \mathrm{Ma}$ (following the last occurrence of Globorotalia fohsi peripheroronda, now called Fohsella 
peripheroronda, defined at 13.8 Ma; Lourens et al., 2005). These Upper Miocene sediments were removed by erosion during the Messinian Salinity Crisis.

A large part of the offshore MES had already been mapped and interpreted. Mapping revealed a pattern of up to $5^{\text {th }}$ order dendritic drainage (Gorini, 1993; Guennoc et al., 2000; Gorini et al., 2005; Bache et al., 2009; Lofi et al., 2011) with two main systems:

(1) the first system, in the east, corresponds to the Rhône together with a network from the region of Montpellier, both of which join downstream to become a single valley;

(2) headward, in the west, the second system extends from the Languedoc and Roussillon regions.

Here, we emphasize the presence of two main incised valleys, located at respectively 1200 and 1400 mSec.TWT on seismic line LRM96-08, i.e. parallel to the Roussillon shoreline (Fig. 2). With respect to the map of the Messinian drainage published by Gorini (1993), we assume that these incised valleys correspond to the distal course of Roussillon rivers during the peak of the MSC (Figs. 1 and 2). In the next section, we focus on their onshore record within the Roussillon Basin.

\subsection{Onshore transects}

Thanks to the large number of wells drilled in the Roussillon Basin mostly to pump water, including three deep industrial boreholes (Ponteilla: Gouzee Group; Canet 1 and Elne 1: Gottis, 1958; Compagnie d'Exploration Pétrolière), we were able to reconstruct three geological transects across the basin, based on 40 boreholes (Table 1): one transverse transect (P1) and two longitudinal ones (P2 and P3) (Fig. 4A). Three of these boreholes have (1) a biostratigraphic record based on planktonic foraminifers and/or calcareous nannofossils and (2) a palaeo-environmental record based on pollen grains and dinoflagellate cysts (Cravatte et al., 1984; Clauzon et al., 1990). These profiles and their interpretation are shown in Figures 4B and 5A, 5B. In addition to the sedimentary logs of the holes, loggings (mainly gamma ray and resistivity) are also available (for details, see: Duvail, 2008; http://www.infoterre.fr).

The south-north $\mathrm{P} 1$ profile crosses the main tectonic faults of the Roussillon Basin, the Albères and Prades bordering faults, and two intra-basin faults (the Elne and Canet faults) (Fig. 4). In the Canet 1 section (Figs. 1B, 4B; Table 1), a long sedimentary gap was evidenced at depth of $825 \mathrm{~m}$ (i.e. $821.28 \mathrm{~m} \mathrm{bsl}$ ), documented by planktonic foraminifers, i.e. the record of Globigerinoides sicanus at depth of $826 \mathrm{~m}$ and that of Globorotalia margaritae, Globigerina nepenthes and Sphaeroidinellopsis subdehiscens at $825 \mathrm{~m}$ (Clauzon and Cravatte, 1985). Indeed, G. sicanus (i.e. Orbulina sicana in the modern nomenclature) disappeared at $14.53 \mathrm{Ma}$ and G. margaritae (Hirsutella margaritae in the modern nomenclature) appeared at $5.08 \mathrm{Ma}$ in the Mediterranean (Lourens et al., 2005). The MES was consequently located at this level (Clauzon and Cravatte, 1985; Clauzon, 1990; Clauzon et al., 1990). In the Elne 1 section drilled on a structural high, a sudden lithological shift was observed from continental greenish sands to marine blue sands and clays at a depth of $366 \mathrm{~m}$ (i.e. 221 m bsl) (Fig. 4B; Gottis, 1958) which locates Globorotalia margaritae at a depth between 262 and $248 \mathrm{~m}$ (Cravatte et al., 1984; Clauzon, 1990). The MES was located there (Fig. 4B; Clauzon, 1990; Clauzon et al., 1990). The profile of the MES was reconstructed by Duvail et al. (2000) using the seismic profiles acquired during exploration for hydrocarbons (Cox, 1952; Welsh, 1954). The MES cut into the tectonic structure of the basin, the morphology of which forced the course of the Messinian rivers (Fig. 4B). In addition, the present-day Agly and Têt rivers are superimposed on their respective Messinian streams, however, the course of the Tech 
River is not the same because of the Late Pliocene - Early Quaternary "aggradation epigenesis" phenomenon (Fig. 4b; Clauzon et al., 1990, 2015; Clauzon, 1996).

The west-east P2 profile follows the Têt River almost continuously from the Millas area to the Mediterranean shoreline, where it correlates with the P1 profile through the Canet 1 borehole (Figs. 4A, 5A; Table 1). Near Millas, the (possibly slightly or not at all) uplifted MES was identified in several exposed sections at an altitude of $120 \mathrm{~m}$ asl (see the following section). The MES is $821.28 \mathrm{~m}$ bsl in the Canet 1 wells, revealing an average dip of about $3.5 \%$.

The P3 west-east profile starts from well 29 drilled south of Thuir and ends on the Mediterranean coastline after crossing the Elne 1 hole (Figs. 4A, 5B; Table 1). The contact between Miocene deposits and Pliocene clays made it possible to depict the MES from hole 29 (3 m bsl) to Ponteilla hole (168 m bsl) and Elne 1 well (369 m bsl).

\subsection{Exposed evidences}

Ten locations were selected as reliable examples of the MES in exposed sections (a, d, f, i, j, 1, m, o, q and r; Fig. 1B). They are presented from north to south with reference to the mapped MES.

Near Leucate, a comprehensive section is visible at Codequas along the D627 road (42 ${ }^{\circ} 54^{\prime} 38.80^{\prime \prime} \mathrm{N} ; 3^{\circ} 1^{\prime} 15.02^{\prime \prime} \mathrm{E}$; altitude: $20 \mathrm{~m}$; Fig. 1B). The section includes three sequences separated by two erosional surfaces (Fig. 6). Based on the presence of rodents, the lower sequence, which is made of coastal deposits evolving from sands to a molasse with megaripples rich in oysters, is late Burdigalian to early Langhian in age (Aguilar and Magné, 1978). The intermediate sequence is composed of conglomerates that filled the fluvial channels. The upper sequence contains loams typical of the flood plain topped by palustrine to lacustrine limestones and marls, characterized by a reverse paleomagnetic signal, which, there and in nearby La Franqui (Fig. 1A), yielded small mammals from the Pliocene (Aguilar, 1977), which Clauzon (1990) ascribed to the late Zanclean. The lower erosional surface corresponds to a fluvial network that developed extensively in southern France during the Tortonian because of tectonic uplift. In this way, there is no long sedimentary gap between the cutting of the erosional surface and the subsequent filling with sediments. The upper erosional surface is the Messinian surface because it is intercalated between the Tortonian and Zanclean deposits. This surface corresponds to a sedimentary gap, which, according to Bache et al. (2012), lasted for the duration of the sea level drawdown of the MSC, i.e. $140 \mathrm{kyrs}$ from 5.6 to $5.46 \mathrm{Ma}$. The outline of the Miocene-Pliocene contact is accurately recorded on the Leucate map (Berger et al., 1982), but unfortunately no information is provided about its erosional nature.

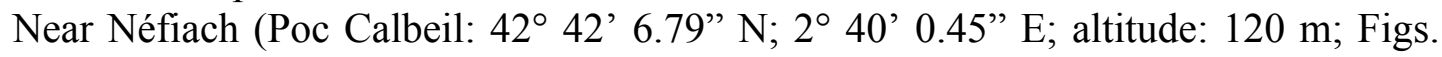
1B, 7B), a well-exposed discontinuity separates the Pliocene marine deposits from the metamorphic basement (Fig. 7C). No fault plane or tectonic breccia are visible but mapping shows a sinuous contact that resembles fluvial meanders, thus emphasizing palae-orelief of the Hercynian basement after marine reflooding (Fig. 7B). This morphology was forced by fluvial erosion preceding the well-dated overlying Zanclean sediments (nannofossils: Cravatte et al., 1984; mollusks: Depéret, 1890-97; Martinell and Doménech, 1990; mammals: Depéret, 1890-97). It was concluded that this erosional surface represents the MES (Clauzon, 1990; Clauzon et al., 1990). Although the MES is described in the booklet of the Rivesaltes geological map (Berger et al., 1993), it is regrettable that an appropriate symbol was not used to show its outline on the map (Fig. 7A), which is a handicap with respect to the maps published by Clauzon (1990) and Clauzon et al. (1990) reproduced here (Fig. 7B). 
At the locality called Les Orgues northward of Ille sur Têt $\left(42^{\circ} 40^{\prime} 48.91\right.$ ' N; $2^{\circ} 36^{\prime}$ 39.17" E; altitude: $179 \mathrm{~m}$; Figs. 1B, 7E), the contact between the marine Pliocene sediments and the granite is erosional (Fig. 7F) and has the same jagged shape as at Néfiach (Fig. 7E). The uppermost marine sediments overlying this surface provided a Zanclean rhinoceros (Guérin, 1975). As a consequence, this surface was considered to be the MES (Clauzon, 1990; Clauzon et al., 1990). As explained above referring to Néfiach, the Rivesaltes geological map (Fig. 7D; Berger et al., 1993) does not highlight the MES, but it is on the Clauzon's map reproduced here (Fig., 7E; Clauzon, 1990; Clauzon et al., 1990).

The Pliocene continental deposits can be traced upstream from Ille sur Têt (Fig. 8D) to the area of Serdinya (Fig. 8F). The deposits are made up of grayish sands including blocks of older rocks. Behind Vinça, these deposits, devoid of any fossil, are known as the Escaro Formation (Figs. 8D, 8F; Pannekoek, 1935). This formation constitutes the subaerial sedimentary prism that was the inland extension of the Pliocene submarine prism (Fig. 8D). As observed in many places, the Escaro Formation rests with erosive unconformity upon:

- older deposits, i.e. the red detritic Codalet Formation (examples from Villerach and Catlar: Figs. 1B, 8C), which is the lateral equivalent of the Marquixanes Formation (Pannekoek, 1935) dated early Burdigalian based on mammal fauna at La Lentilla (Baudelot and Crouzel, 1974);

- rocks of the basement (e.g. at Coma del Mas: Figs. 1B, 8A). The Escaro Formation is nested in the Codalet Formation (Fig. 8B). This contact was previously thought to be of tectonic origin (Fig. 8E; Bandet, 1975; Guitard et al., 1998; Calvet and Gunnell, 2008). However, this analysis is contradicted by the absence of fault planes and tectonic breccias and by the jagged outline of the contact (Fig. 8F) described above for the Néfiach area. This erosional truncation is evidence for the MES, and can also be observed in the La Lentilla section just above the fossiliferous bed with respect to the drawing by Bandet (1975) and our examination.

The profiles connecting the boreholes in the entire Roussillon Basin allow the continuous identification of the continental Pliocene (Fig. 5; Duvail, 2008). Specifically, the unconformity of the Pliocene red loams including pebbles with Miocene brownish conglomerates is well-exposed at Rigall near Thuir (Figs. 1B, 9). The topography shows that the continental Pliocene sediments are nested inside the Miocene ones and more generally within the basement. This contact thus corresponds to the Messinian Erosional Surface (Fig. 9).

In the southern part of the basin, the MES can be traced for long distances along the Tech River, for example near Le Boulou, Vivès and Céret (Fig. 1B). In this area, its gullying outline is particularly well-expressed enabling us to strongly reassert that this surface cannot be a fault or a succession of faults, as proposed in the newly published geological map of Céret (Fig. 10B), available online (http://www.infoterre.fr: map 1096; Donzeau et al., 2010). The contact between marine or continental Pliocene sediments and the metamorphic basement is erosive (Fig. 10). Most of this contact is unexplained on the newly published map (Fig. 10B), and in some places, is denoted as a hypothetical fault.

In fact, the set of the geological maps of the Roussillon Basin published by the French Geological Survey (B.R.G.M.) is incongruent ${ }^{1}$, as it includes maps in which the erosional impact of the MSC is:

\footnotetext{
${ }^{1}$ Argelès (1097) is the last map and has still not been published.
} 
- taken into account (1090 Rivesaltes: Berger et al., 1993; 1091 Perpignan: Clauzon et al., 1989),

- ignored (1095 Prades: Guitard et al., 1998; 1079 Leucate : Berger et al., 1982),

- denied (1096 Céret: http://www.infoterre.fr; Donzeau et al., 2010).

For these reasons, a detailed map was drawn to homogeneously represent the Messinian subaerial erosion at basin scale (Le Strat et al., 2001). This map was updated, particularly the Conflent area, and is provided at high resolution as Supplementary data 1 . The new map was drawn by combining our published (Clauzon et al., 1989, 1990; Berger et al., 1993) and unpublished geological surveys. It is intended to draw attention to the above mentioned contradiction between the Roussillon set of 1:50,000 scale geological maps, in complement to the $6^{\text {th }}$ edition of the 1:1,000,000 scale geological map of France on which the MES is drawn along the Mediterranean coastline and extends deep inside the Rhône Valley (Chantraine et al., 2005).

Mapping the MES not only raises theoretical and technical questions, but also conflicts with conceptual blockings. With respect to the three kinds of behavior mentioned above (being taken into account, ignored, or denied) concerning the MES it is not rare that extreme contradictions arise. For example, Roveri et al. (2009) acknowledged a clearly demarcated inland (necessarily subaerial) MES in the peripheral Sorbas Basin. On the contrary, the same authors defended a submarine MES in the entire Mediterranean Basin but restricted to the continental slope, thereby denying its fluvial origin (Roveri et al., 2014b). However, the development of the MES during the peak of the MSC is generally widely accepted (see for example: CIESM, 2008; Roveri et al., 2014a) because it has been observed all around the Mediterranean Basin (Bache et al., 2012). Technically speaking, the MES can be observed onland in the bottom and edges of the peripheral basins, as we did in the Roussillon Basin (Figs. 6-10). Its dip is sometimes steep but not everywhere, especially where the aggrading continental Pliocene may be conformable over the older rocks. In such a situation, the contact is not an angular unconformity but only a chronostratigraphic gap and the label MES should be replaced by "Messinian Discontinuity" (for details and examples, see: Melinte-Dobrinescu et al., 2009; Do Couto et al., 2014; Clauzon et al., 2015). These features lead us to believe that the future representation of the MES will be a three-dimensional interpolation based on field surveys, seismic profiles and well sections.

\subsection{Three-dimensional reconstruction}

The 3D geometry of the MES in the Roussillon Basin was built using the 3D Geomodeller software (BRGM - Intrepid Geophysics). This software is able to interpolate a surface based on external (outcropping geological interfaces, orientations) and internal data (well tops, depth migrated seismic images) using a cokriging method (Calcagno et al., 2008; Guillen et al., 2008). During the modeling process, the sequence of interpolation of geological units is given by a synthetic geologic pile that accounts for the nature of the contacts separating geological units: "erosive" in the case of an unconformity or "onlap" in the case of a sedimentary filling, for instance (for details, see: Calcagno et al., 2008; Do Couto et al., 2015). In the present case, the MES is constrained as an erosive surface.

Two different types of superficial data were used as inputs for the $3 \mathrm{D}$ modeling process: (1) the updated geological map of the Roussillon area (Supplementary data 1) where the MES is exposed, (2) a Digital Elevation Model (DEM) with a $30 \mathrm{~m}$ resolution, provided by ASTER GDEM, which enables interpolation of the MES up to 
the topography, and (3) field orientation data on the MES (dip and direction). The procedure chosen to constrain the topographic outline of the MES was to digitize multiple control points along the MES outline, spaced 1 to $2.5 \mathrm{~km}$ apart (Fig. 11B). In addition, we used a set of 43 depth migrated seismic profiles (SNPLM-CFP, 1954) tied to the Canet 1 and Elne 1 wells (Fig. 11A). It should be noted that the depth of the MES in the Ponteilla borehole was not input in the modeling process so as to check and control the modeled depth after interpolation. Offshore, the depth of the MES was constrained by previous works by Guennoc et al. (2000) and Gorini et al. (2005).

The result of the interpolation (Fig. 11A) shows that the MES is characterized by a general deepening westward toward the Gulf of Lions. Its current altitude extends from $+970 \mathrm{~m}$ at the contact between the westernmost continental Pliocene deposits and the basement (Supplementary data 1), to $-900 \mathrm{~m}$ near the coastline. The MES geometry indicates the existence of two main valleys that most probably mark the subaerial erosion of the Têt and Tech palaeo-rivers, from north to south respectively, during the paroxysm of the MSC. The lack of deep seismic or well data across the whole basin prevents recognition of second-order streams. North of the Leucate Lagoon, the geometry also suggests the occurrence of a small Messinian valley dipping east-south east (Fig. 11A) which is probably the palaeo-Agly River. The easterly-oriented oblique 3D view of the MES (Fig. 11B), surrounded by the current relief, predicts the morphology of the exposed landscape during the peak of the MSC where the regressive erosion runs up to the Prades area. The interpolation of the MES was controlled thanks to the depth of this surface in the Ponteilla well (Fig. 11A). The MES was observed at $167 \mathrm{~m}$ bsl (i.e. at a depth of $267 \mathrm{~m}$ ) and the result of interpolation predicts a depth of $275 \mathrm{~m}$ (Fig. 11A). This difference of ca. $8 \mathrm{~m}$ represents a $<3 \%$ error rate, which, with regards to the input dataset, is acceptable and confirms the reliability of the modeled surface.

We wish to underline how essential mapping the MES (or the Messinian Discontinuity) is around the Mediterranean region s.l., i.e. including the eastern part of the former Paratethys (Bache et al., 2012). Three-dimensional mapping is a very promising way to record the Messinian erosion, as shown by first attempts concerning the Rhône Valley (Schlupp et al., 2001; Gargani, 2004; Gorini et al., 2005; Loget et al., 2005; Roure, unpublished) and the Roussillon Basin (Gorini et al., 2005). This progress is all the more important as it is a significant contribution to the 3-D B.R.G.M. program on the Pyrenees in the framework of the French Geological Reference Platform.

\section{The post-MSC marine reflooding and sedimentary filling}

\subsection{Gilbert-type fan deltas in the proximal parts of the rias}

Immediately after the marine reflooding, dated at 5.46 Ma (Bache et al., 2012), the sedimentary filling of the Messinian valleys, suddenly transformed into rias, started with debris flows made of large blocks (e.g., reworking the granite at Les Orgues of Ille sur Têt: Figs. 1B, 7F). This coarse sedimentation was rapidly followed by the construction of a Gilbert-type fan delta like in many places around the Mediterranean (Bache et al., 2012). These Gilbert-type fan deltas have been already described in detail by Clauzon (1990) and Clauzon et al. (1990). The marine fauna recorded in their bottomset beds provided an early Zanclean age (nannofossils: Cravatte et al., 1984; mollusks: Martinell and Doménech, 1990). One of the best-preserved Gilbert-type fan deltas is located at Bente Farine near Néfiach (Fig. 1b), deposited by a tributary of the Têt River (Fig. 12). A long axial Gilbert-type fan delta cut by the modern Tech River 
is exposed downstream of Le Boulou (Fig. 1B). It has been ascribed to Zanclean by the mollusks from Nidolères (Martinell and Doménech, 1990). The clayey bottomset beds, 80 m-thick (Suc and Fauquette, 2012), were analyzed paleomagnetically. They show one reversal topping a normal episode (Lindsay, 1985), which was ascribed to Chron C3n.4n (Aguilar et al., 1999) because they were deposited after the Vivès 2 mammal locality (Els Pontells; Fig. 1A), at the earliest Zanclean (Clauzon et al., 1987) with a reverse paleomagnetic signal (Aguilar et al., 1999). These Zanclean Gilberttype fan deltas are steep-sided within the proximal part of the rias and relatively limited in space. Basinward, prograding widely spread sedimentation relieves the Gilbert-type fan deltas (Figs. 4 and 5).

The Gilbert-type fan deltas contain a significant reference layer, which separates the subaqueous bottomset and foreset beds from the subaerial topset beds (Gilbert, 1885, 1890): this layer is the marine-continental transition (Bache et al., 2012). The Zanclean Gilbert-type fan deltas of the Roussillon Basin exhibit this transition in many places relatively close to the MES revealing how rapidly marine sediments filled the proximal part of the rias. This layer is characterized by an angular discordance between the gray sandy to gravelly foreset beds $\left(20^{\circ}<\right.$ dip $<40^{\circ}$; Clauzon et al., 1990) and the almost horizontal brownish to reddish conglomeratic topset beds (Figs. 12B, 13). In some places, a condensed bed may highlight the discordance, such as a mollusk coquina at Poc Calbeil (Néfiach; Figs. 13A-B) or a lignite at Els Pontells (Vivès; Fig. 13D) (see Fig. 1B for location). Examination of the marine-continental transition enabled the deposit profile of the topset beds to be reconstructed: alluvial cones at Les Escoumes, braided fluvial facies at Bente Farine, interfluvial marshes with lignites at Els Pontells, bioherm with bivalves at Poc Calbeil, and beach facies with pebbles at Saint-Martin (sites g, e, r, d, and c in Figure 1B). The beach environments may be referred to the sea level between 5 and $3.9 \mathrm{Ma}$, which progressively rose from ca. +20 $\mathrm{m}$ (Millas palaeo-beach, for example) to ca. $+60 \mathrm{~m}$ (saxicaved top surface at La Franqui) (Gorini et al., 2014).

\subsection{Record of fluctuations in the post-reflooding sea level}

Five sedimentary sequences were evidenced in the Canet 1 and Elne 1 boreholes (Fig. 4B) and correlated within the basin through several profiles based on wells (Duvail and Le Strat, 2002; Duvail, 2008), e.g. Profile 3 in Figure 5B. This stratigraphic sequence reveals that several transgressive prisms made of marine sands protruded deep into the basin resulting in some changes in sedimentation in the upper part of the Gilbert-type fan deltas. Such prisms probably momentarily moderated the sedimentary progradation and seaward shifting of the coastline (Duvail and Le Strat, 2002; Duvail, 2008).

The western end of these transgressive prisms can be observed at Bente Farine (Néfiach; Fig. 1A) where they overlie the marine-continental transition (Fig. 14A). The prisms are characterized by fine gray sands intercalated in the alluvial reddish gravels and pebbles (Fig. 14B). They pinch out to the west. Such repeated alternations can also be observed at Saint-Martin (Millas; Fig. 1B) and near Le Boulou. The youngest marine intercalation is exposed at Ribèral (Trouillas; Fig. 1A) where gray marine fine sands (Figs. 15A-B) are overlain by a $1 \mathrm{~m}$-thick coquina almost exclusively composed of Ostrea cucullata (Martinell and Doménech, 1990; Figs. 15A and C), marking the final passage to alluvial deposits. The thin lignitiferous clayey bed sandwiched between the gray sands and the coquina (Fig. 15C) displays a reverse paleomagnetic signal. The section is a little younger than the La Jasse section (Terrats; Fig. 1B; Suc, 1976), which contained small mammals (Michaux, 1976), and displayed 
a reverse to normal paleomagnetic signal (Lindsay, 1985). Aguilar et al. (1999) correlated it with the $\mathrm{C} 3 \mathrm{n} .2 \mathrm{r}-\mathrm{C} 3 \mathrm{n} .2 \mathrm{n}$ reversal.

We re-examined the Roussillon pollen records (Suc, 1976; Cravatte et al., 1984; Suc and Fauquette, 2012) in order to construct the "Halophytes/Pinus" curve. Halophytes are plants restricted to coastal environments (Amaranthaceae-Chenopodiaceae, Plumbaginaceae, Caryophyllaceae, Ephedra, Tamarix), the pollen of which is weakly transported offshore. In contrast, the pollen of Pinus is easily transported (Beaudouin et al., 2007). This ratio reliably informs on shifting shoreline: seaward when halophytes are prevalent (regressive context), landward when Pinus is prevalent (transgressive context) (Suc et al., 1995a; Bache et al., 2012). This ratio was established on four pollen records: Le Boulou and the wells Elne 1, Canet 1 and Mutualité agricole F1, where the sequences S1 to S4 are located (Fig. 16). Although Sequence S1 of the Elne 1 and Canet 1 sections were deposited relatively far from the palaeo-shoreline, the pollen ratio consistently documents some variations in the base level in a context of high sea level. The thick clayey succession at Le Boulou is correlated with Sequence S2 because (1) it is relatively distant from the tip of the ria (Fig. 1B) and (2) it belongs to paleomagnetic Chron C3n.4n (see above). The pollen ratio indicates high sea level conditions, as also documented by the Elne 1 and Canet 1 successions for the same sequence. Sequence 3 shows alternating recession and advance of the seashore in the inner localities Elne 1 and Mutualité agricole F1 in contrast to that at the more distal site of Canet 1 . Sequence 4 is characterized by the final advance of the land against the sea up to modern condition. Indeed, the end of the pre-Quaternary history of the Roussillon Basin is marked by a land-to-sea instructive surface.

\subsection{The surface topping the sedimentary filling}

Sedimentary filling of the Roussillon Basin culminated in a slightly seaward dipping surface located at $196 \mathrm{~m}$ asl at Pla del Rey, dated around $4 \mathrm{Ma}$ by the reverse paleomagnetic signal of the underlying deposits, which provided the Perpignan mammal fauna at Serrat d'en Vacquer, placed within Chron C2ar (Figs. 1B, 17A-B, 18; Lindsay, 1985; Aguilar et al., 1999). The Leucate carbonated Formation (Figs. 1B, 6) is regarded as equivalent to foreset beds in a lateral position outside the main terrigenous inputs. From Leucate to La Franqui (Fig. 1B), the plateau which, at $60 \mathrm{~m}$ asl tops this formation, is the coastal extension of the Pla del Rey surface (Fig. 17C). This plateau was momentarily covered by the sea as indicated by dense borings made by saxicavous mollusks (Fig. 17D). Beneath the carbonates, palustrine clays provided micromammals at La Franqui (Fig. 17C). These clays showed a reverse paleomagnetic signal and were thus also ascribed to Chron C2ar (Fig. 18). The poor micromammal fauna was first considered to be Piacenzian in age (Aguilar, 1977). However, differences between this fauna and the Serrat d'en Vacquer microfauna (Mein and Aymar, 1984) are so small that consistent with the geometrical relationships at the basin scale, a late Zanclean age must be considered. At Serrat d'en Vacquer, the top of continental deposits lies at $100 \mathrm{~m}$ asl. According to Clauzon et al. (1990), the top 50 meters may have been removed by erosion. The altitude of this surface decreases from the inner basin to the palaeoshoreline. It is slightly tilted seaward, probably, like the underlying sediments, as a result of subsidence, particularly during reconstruction of the shelf since $3.8 \mathrm{Ma}$.

The volume of prograding Pliocene sediments that fill the Roussillon rias corresponds to the volume between the MES and the Pliocene abandonment surface. To calculate this volume, this abandonment surface was reconstructed from field 
evidences completed by the automatic extraction of the main remnant high points and crests in the Roussillon Plain (Fig. 11C). The elevation of this surface was then corrected by the value of post-deposition denudation estimated to be $50 \mathrm{~m}$ at "Serrat d'en Vaquer" based on geomorphic evidences (Clauzon et al., 1990), which is assumed to be the same in the whole rias. The total volume of the Pliocene sediments deposited in the present-day onshore domain obtained is $\sim 400 \mathrm{~km}^{3}$.

\subsection{Attempt at correlation with sea level fluctuations}

By combination of stratigraphic data, dynamics of sedimentary filling, marine biostratigraphy (Canet 1 - Elne 1 - Mutualité agricole F1 holes), continental biostratigraphy (Vivès 2, Terrats, Serrat d'en Vacquer, La Franqui), and magnetostratigraphy (Vivès 2, Le Boulou, Banyuls dels Aspres, Terrats, Trouillas, Serrat d'en Vacquer, La Franqui), we obtained a chronological and geodynamical scheme of the Roussillon Basin since the MSC. This scheme was tested with regards to the fluctuations of the global sea level (Miller et al., 2011; Gorini et al., 2014) (Fig. 18). We consider these global sea level curves, which are very different in amplitude and resolution of fourth order fluctuations, together, because (1) the altitudinal value of the post-MSC sea level deduced from our field investigations is in good agreement with the Gorini et al.'s curve, and (2) our sedimentary sequences S1 to S5 can be accurately compared with the Miller et al.'s curve. Such a comparison makes it possible to moderate the effect of the 1-Myr high still stand in the Early Pliocene on sedimentation (Haq et al., 1987), as previously considered by Clauzon (1990) and Clauzon et al. (1990). Taking into account (1) the magnetostratigraphic ascription of several sections (see details above) and (2) the correlations with the sequence stratigraphy in wells Canet 1 - Elne 1 - Mutualité agricole F1, we can tentatively summarize the history of the Roussillon Basin during the time-interval $6-3 \mathrm{Ma}$ (Fig. 18):

- between 5.60 and 5.46 Ma (i.e., the peak of the MSC; Bache et al., 2012), intense fluvial erosion impacted the basin previously filled with Miocene sediments, and weakly eroded during the Tortonian;

- at 5.46 Ma, the sudden instantaneous return of marine waters into the Mediterranean Basin entirely flooded the Roussillon Basin and transformed the Messinian valleys into rias;

- from 5.46 to ca. 5.25 Ma, a relatively stable highstand of sea level favored the development of Gilbert-type fan deltas, particularly in the lower part of Sequence S1;

- from ca. 5.25 to ca. 4.90 Ma, progradation continued in the context of a high sea level with some variability (Sequence S2);

- from ca. 4.90 to ca. $4.40 \mathrm{Ma}$, significant changes in the sedimentary dynamics affected the basin (Sequence S3), probably in relation with variations in the falling sea level;

- from ca. 4.40 to ca. $4.30 \mathrm{Ma}$, the rise in sea level may have resulted in a minor invasion of the basin by marine waters, marked by the Trouillas succession (Sequence S4) before the final supremacy of continental sedimentation;

- from ca. 4.30, continuing vertical aggradation of continental sedimentation (Sequence S5) which ended around 4.05 Ma probably correlated with a slight fall in sea level;

- the following high sea level $(4.00-3.90 \mathrm{Ma})$ would have resulted in the invasion of the Leucate - La Franqui Plateau by marine waters; 
- finally, the significant fall in sea level at $3.80-3.40 \mathrm{Ma}$ is likely at the origin of the erosion observed at the Trois Frères Cape (La Franqui; Fig. 1B), above which a coarse breccia was deposited (Fig. 17C).

This step in studying the Roussillon sedimentary filling during the Pliocene is based on high-resolution analysis of present-day deposits and surface geometries within the stratigraphic frame. Some of the factors that were previously thought to have somewhat increased terrigenous sedimentation, such as climate and tectonic uplift, are now considered to have had only a minor effect. Indeed, the climate varied very little from 5.46 to 3.37 Ma (Suc, 1984; Suc et al., 1995b; Popescu et al., 2010). Most of the modern altitude of the Eastern Pyrenees was acquired at the earliest Zanclean and the uplift then continued in a constant but moderate way (Suc and Fauquette, 2012). As a consequence, we can consider that the main controlling factors were changes in sea level and subsidence. A forthcoming reconstruction of the original sedimentary prisms is to be applied onshore to the successive marine-continental alternations within the frame of tilting continuously induced by differential compaction of deposits during the Zanclean.

\subsection{Estimate of subsequent erosion using cosmogenic nuclide 10Be concentration}

Palaeo-denudation rates of the Pliocene Roussillon catchment were estimated using concentrations of in-situ produced cosmogenic nuclide ${ }^{10} \mathrm{Be}$ measured in topset bed sands. Indeed, rocks exposed to cosmic rays accumulate cosmogenic nuclides whose concentrations depend on their production rates $(\mathrm{P})$, their half-lives and the denudation rates (e.g.: Gosse and Philips, 2001; Dunaï, 2010). If the exposure duration to cosmic ray derived particles is lasts long enough, cosmogenic nuclide concentrations reach a steady-state equilibrium at which the gain in cosmogenic nuclides due to production balances losses due to denudation and radioactive decay (e.g., von Blanckenburg, 2005). At the catchment area scale (A), gain due to production is ( $\mathrm{P} \times \mathrm{A})$, while losses can be estimated by the mean concentration in grains in the river sediments at the outlet (C) multiplied by the sediment flux (F). The concentration of a cosmogenic nuclide $(10 \mathrm{Be})$ measured in sediments sampled at river outlets makes it possible to estimate the sediment flux (and hence the denudation rate) at catchment scale, assuming steady-state concentrations within the catchment (Brown et al., 1995; Bierman and Steig, 1996; Granger et al., 1996). When the sediments are buried deeply enough rapidly after their deposition, the concentration is only affected by radioactive decay. If the burial age and the production rate are known, it is thus possible to determine the palaeo-denudation rate of the corresponding catchment at the burial time. This is the only method that makes possible to obtain absolute values for denudation rates (Dunaï, 2010).

We analyzed two topset sandy samples from Roussillon corresponding to the two main rivers, the palaeo-Têt and palaeo-Tech. Sands were sampled on anthropic outcrops. ${ }^{10} \mathrm{Be}$ concentrations were measured at the French National Accelerator Mass Spectrometry facility (ASTER), in CEREGE, Aix en Provence. The detailed method used for the chemical preparation and the values used to calculate the denudation rate are detailed in Supplementary data 2 and 3, respectively. The deduced palaeodenudation rates are $27 \pm 4 \mathrm{~mm} \mathrm{ka}^{-1}$ for the Têt River and $52 \pm 12 \mathrm{~mm} \mathrm{ka}^{-1}$ for the Tech River. These values can be compared to those measured in the present-day river sediments using the same method: $132 \pm 47 \mathrm{~mm} \mathrm{ka}^{-1}$ for the Têt River and $104 \pm 24$ $\mathrm{mm} \mathrm{ka}^{-1}$ for the Tech River (Molliex et al., 2012). Denudation rates determined from Pliocene sediments appear to be 2 to 3 times lower than those determined from present-day sediments. Even if we do not know the exact climatic conditions that 
prevailed during deposition of this specific Pliocene sample due to major uncertainties on ages, it is interesting to note that the ratio between Pliocene and present-day denudation rates is of the same order of magnitude as that inferred for the Gulf of Lions catchment from volumes of onshore sediments (Leroux, 2012). These low rates can be interpreted as resulting from differences in climatic conditions that control chemical weathering or as a decrease in incision and in mechanical erosion due to the rise of the base level during reflooding.

\subsection{Estimated age of the end of infilling}

Thanks to denudation rates deduced from cosmogenic nuclides, the volume of Pliocene sediments filling the Roussillon rias was calculated from the reconstruction of the MES and abandonment surface (Section 3.3; Fig. 11C), and from the drainage area of the Pliocene rias. The time needed to fill the Roussillon rias by aggradation can also be estimated. Assuming that no major change in drainage has occurred in the Roussillon watershed since the MSC, we estimate the drainage area of the Roussillon rias to about $2720 \mathrm{~km}^{2}$ (Fig. 11C). Assuming a constant mean Pliocene denudation rate of $39.5 \pm 20.5 \mathrm{~mm} \mathrm{ka}^{-1}$, the denudation of the catchment involves a volume of eroded rock of $118 \pm 56 \mathrm{~km}^{3}$ per million years. Taking into account a mass of $2.5 \mathrm{t} \mathrm{m}^{-3}$ for the catchment rocks and $2.2 \mathrm{t} \mathrm{m}^{-3}$ for the Pliocene sediments, the minimum time needed to fill the entire rias is $2.0 \mathrm{Ma}$. These results can be compared with other data, such as field evidences and mammal faunas magnetostratigraphically calibrated, since canyon infilling is estimated to have ended at about 4.0 Ma (Fig. 18). Using the same method, we estimate the total volume of sediment needed to fill the Roussillon rias up to the Serrat d'en Vacquer at about $200 \mathrm{~km}^{3}$, assuming a palaeo-coastline parallel to the reconstructed isolines of the Pliocene abandonment surface. The time needed to fill this volume was calculated to be from 1 to $2.8 \mathrm{Ma}$. If the filling of palaeo-valley began at $5.46 \mathrm{Ma}$ (Bache et al., 2012), the infilling of the basin at Serrat d'en Vacquer would have ended at $3.6 \pm 0.9 \mathrm{Ma}$. This value is consistent with the age (4.0 Ma) estimated using other approaches (Fig. 18). Uncertainties on the denudation rate are too high to determine the exact end of ria infilling with the present-day coastline, but it gives a maximum age of 3.4 Ma. Moreover, larger scale fluctuations in sea level since $3.4 \mathrm{Ma}$ (Miller et al., 2011; Gorini et al., 2014) make the history of infilling complex, and the assumption of a constant denudation rate probably wrong. In any case, the predicted age does not contradict the marine flooding of the Leucate - La Franqui Plateau estimated at 3.8 Ma (Fig. 18).

\section{The Prades olistostrome on the northern flank of the Canigou Mount}

The Canigou Mount is the easternmost part of the axial zone of the Pyrenees Mountains. This is a mega-anticline, which folded the deep thrust sheet made of augen gneisses derived from ante-Hercynian granites (Guitard et al., 1998). Alpine tectonics resulted in faulting which structured the area into several units. The Neogene uplift is well-expressed in the Prades Basin.

An impressive dismantled unit composed of basement rocks (schists, orthogneisses, etc.), on the northern flank of the Canigou Massif has long been known as the Canaveilles and Escaro slices (Furon, 1940). Thanks to extensive exploration for fluorite mining, Huard and Pelissonnier (1969) established that these slices are actually a huge olistostrome. For these authors, the olistostrome collapsed in the late Pliocene because it is sandwiched inside the Escaro Formation (see: Figs. 8F, 19C), which Pannekoek (1935) and Oele et al. (1963) ascribed to this period. This 
stratigraphic relationship and the above-mentioned age were not accepted in the Prades geological map, on which the olistostrome overlies the Escaro Formation, which is considered to be Miocene (Guitard et al., 1998).

\subsection{When did the olistostrome set up?}

We re-examined and accurately mapped the olistostrome with respect to the impact of the MSC (Figs. 8F; Supplementary data 1). The olistostrome outcrops southeast of Clara up to west of Escaro (Figs. 8F, 19A). The impressive decollement facets can be traced from the top of the olistostrome (about $1150 \mathrm{~m}$ asl) up to an altitude of $1500 \mathrm{~m}$ (Figs. 19B, 20C) and provides accurate information concerning the starting position of this huge transported mass. At the Saint-Eusèbe pass, the Escaro Formation (Figs. 8AC) both underlies and overlies the olistostrome (Figs. 19D-F). A similar context is observed at the La Llosa pass, $1.6 \mathrm{~km}$ west of Escaro (Supplementary data 1). As the Escaro Formation was deposited during the Zanclean (Section 2.3), we conclude that the Prades olistostrome tumbled down into the valley after the marine reflooding of the Mediterranean Basin and before the complete filling of the Roussillon Basin with sediments. Accordingly, we tentatively place this local but outstanding event at about 4.50 Ma (Fig. 18).

\subsection{Interest of the olistostrome to reconstruct the uplift of the Canigou Massif}

Several reference layers or surfaces mark the geodynamic evolution of the Canigou Massif. Some refer to sedimentation, others have an erosive origin. They may reconstruct the palaeoaltitude of the Massif for the time-interval $6-4 \mathrm{Ma}$, which encompasses the MSC (Fig. 20).

At Les Escoumes (Vinça; Fig. 1B), the marine-continental transition is at $270 \mathrm{~m}$ asl (Fig. 13C). Longitudinal relationships inside the basin suggest that it belongs to sequence S4 (Fig. 5A), i.e. at about $4.40-4.30 \mathrm{Ma}$ (Fig. 18). The global sea level curve suggests that this marine-continental transition developed $+70 \mathrm{~m}$ above the present-day sea level (Fig. 18; Gorini et al., 2014). As a consequence, the marinecontinental transition there has probably risen around $200 \mathrm{~m}$ since the late Zanclean, that confirms the relatively weak epeirogenic uplift of the Canigou Massif since that time.

The Oligocene - Miocene planation surface was formed before the opening of the Gulf of Lions (Gunnell et al., 2009), i.e. before the rifting of the Corsica-Sardinia block (Mauffret et al., 2001). This surface is preserved at a few locations in the Roussillon area: at Montalba le Château, $5 \mathrm{~km}$ NW of Ille sur Têt (Fig. 1B), today the surface is $430 \mathrm{~m}$ asl and we would expect that it has gone up $200 \mathrm{~m}$ since the Early Pliocene based on the above estimations for nearby Vinça. In the Canigou Massif, one surface, the Pla Guillem, is located at an altitude of $2277 \mathrm{~m}$ asl (Fig. 20D). The origin of such a high altitude surface in the Pyrenees is the subject of heated debate between the defenders of an "uplifted peneplain" (Gunnell and Calvet, 2006; Gunnell et al., 2008) and those of "altiplanation" (Babault et al., 2005, 2006). However, Suc and Fauquette (2012) estimated that an uplift of ca. $500 \mathrm{~m}$ affected the nearby Cerdanya peneplain between 6.5 and 5.3 Ma. As a consequence, it is not unrealistic to consider that before this significant uplift, the Pla Guillem surface was he altitudinal extension of the Oligocene - Miocene planation surface. Using several reference layers in the Conflent area, such as the Oligocene - Miocene planation, the restored pre-MSC abandonment surface, the MES, and the restored Pliocene abandonment surface, Clauzon and Rubino (2001) estimated the uplift at about $500 \mathrm{~m}$ (Fig. 20B). 
Using the two above-mentioned values, $200 \mathrm{~m}$ as epeirogenic uplift and at least 500 $\mathrm{m}$ as reactivation of the Canigou fault, by substraction from the present-day corresponding values, we can estimate an altitude of about 1900-2000 m for the Canigou Mount before the MSC as oppose to 2784 m nowadays (Fig. 20A). Such an altitude is almost consistent with the hypothesis of a possible altitude of about $2200 \mathrm{~m}$ at 6.50 Ma for the more central Puigmal - Carlit nearby massifs (Suc and Fauquette, 2012). In the same way, an altitude of about 1400-1500 m can be estimated for the Pla Guillem surface at the same period (Fig. 20A).

As a consequence, an altitude of about $2600 \mathrm{~m}$ can be predicted for the Canigou Mount and of $2100 \mathrm{~m}$ for Pla Guillem at the end of the MSC (Fig. 20B), respectively. This estimate is consistent with the altitude of the lower limit of the conifer (fir) belt foreseen by Suc and Fauquette (2012) at ca. 2140 m (confidence interval: 1865 - 2360 $\mathrm{m})$.

Some additional information on the amplitude of reactivation of the Canigou fault follows:

- between Millas and Perpignan (Fig. 1B), the Roussillon Basin includes a low plateau near Baixas at an altitude of $112 \mathrm{~m}$ asl, this being a non-uplifted surface since the Mid-Miocene but which developed at sea level at that time (Calvet, 1996), and is consistent with the global eustatic curve (Haq et al., 1987);

- comparing this altitude with that of the Montalba le Château coeval surface (430 $-200 \mathrm{~m}$ corresponding to its already documented post-MSC uplift of $230 \mathrm{~m}$ ), we obtain a difference in palaeoaltitude of $118 \mathrm{~m}$ between Baixas and Montalba le Château, i.e. a dip of $0.57 \%$ for this surface;

- applying this $0.57 \%$ dip to the distance between Pla Guillem and Baixas, we obtain a difference in palaeoaltitude of $261 \mathrm{~m}$ to which we must add the unchanged altitude of the Baixas plateau, giving a Mid-Miocene palaeoaltitude for Pla Guillem of about $373 \mathrm{~m}$, a value consistent with that given by Calvet and Gunnell (2008) at $10 \mathrm{Ma}$.

Calvet and Gunnell (2008) concluded that the present-day relief of the Canigou Massif was almost completely acquired during the last 10 Myrs. This is consistent with the pollen data from the nearby Cerdanya uplifted semi-graben (Suc and Fauquette, 2012). Calvet and Gunnell (2008) did not discuss whether the uplift rate was continuous or fluctuated during the last 10 Myrs, but for the time-interval $10-6$ Ma, Suc and Fauquette (2012) envisaged two options of the dynamics of the Puigmal - Carlit massifs, of which the Canigou Massif is the eastward appendix: a slowdown in uplift to reach a stop or a weak uplift of the scale of $200 \mathrm{~m}$. Also considering the above-mentioned weak epeirogenic uplift since the Early Pliocene, this leads us to envisage that optimal uplift of the Canigou Massif, maybe greater than $700 \mathrm{~m}$ (Fig. 20B), occurred the time interval 6-5 Ma which encompasses the MSC.

In addition, Figure 20 emphasizes other important aspects:

- the disrupted history of the Miocene basin controlled by tectonics from the Pliocene one forced by the major changes in sea level linked with the MSC (see also Fig. 8F);

- the mark of the Tortonian erosion related to the Canigou uplift (Fig. 20A), well indicated by the Thuir Breccia (Fig. 9), that has been estimated at about $300-$ $550 \mathrm{~m}$ in nearby areas free from MSC control (Calvet, 1996);

- the thickness of the residual Lower to Middle Miocene deposits at ca. $500 \mathrm{~m}$ according to exposed sections and wells such as the Prades borehole (1095 4X 0037; http://www.infoterre.fr). 
To summarize, Figure 20 illustrates the structural relief set by the Alpine tectonic phase which, since $6 \mathrm{Ma}$, continues to separate on the one hand the bottom of the Miocene deposits in the Conflent Basin from the summit of the Canigou Mount, on the other hand, the palaeosurface topping the Miocene deposits in the Conflent Basin from its uplifted analog at Pla Guillem. Finally, the Pliocene settling appears to be independent of the structural history of the Eastern Pyrenees and exclusively linked to the desiccation phase of the Mediterranean Basin and its subsequent marine reflooding.

\subsection{Origin of the olistostrome: some impact of the Messinian events?}

The collapse of the Prades olistostrome was probably caused by the exposure of the Canigou fault as a consequence of the uplifting Canigou Mount. A remaining question is to distinguish the amplitude in uplift that occurred during the Tortonian and caused the previously mentioned erosion, from the Messinian one. Pollen records from Cerdanya (localities: Sanavastre, Sampsor, Can Vilella) and Le Boulou may be of some help in this matter (Suc and Fauquette, 2012):

- the Sampsor locality (about $9 \mathrm{Ma}$ ) is characterized by a significant increase in Abies pollen, together with Picea an indicator of a higher coniferous belt, compared with the older Sanavastre locality. This points to some uplift of the surrounding massifs, especially the Puigmal Mount which is structurally correlated with the Canigou Mount;

- the Can Vilella pollen flora (at ca. 6.5 - 6.2 Ma) does not contain a significant amount of pollen of altitudinal conifers, except Cathaya in the uppermost sample. In subtropical China, Cathaya today grows at lower altitudes than Abies (1050$1950 \mathrm{~m}, 1950-2950 \mathrm{~m}$, respectively). This may document some relaxation in uplift and even some erosion of the surrounding massifs;

- the lowermost part of the le Boulou section (5.46 - 5.30 Ma) reveals a welldeveloped Abies and Picea belt over the Cathaya belt. This means that some uplift affected the Puigmal-Canigou massif in the latest Messinian.

The Tortonian uplift of the Eastern Pyrenees appears to have been less marked than the latest Messinian uplift, from $500 \mathrm{~m}$ to more than $1000 \mathrm{~m}$, respectively. Because of its stratigraphic position, the Prades olistostrome collapsed during the Early Pliocene, at around $4.40-4.30 \mathrm{Ma}$ (Fig. 18) because the aggrading continental Escaro Formation was deposited later than the marine-continental transition, which, at Vinça (Fig. 8D), represents the upper part of Sequence S4 (Fig. 5A).

Because of this accurate dating, we can hypothesize that the increased throw of the Canigou fault was the consequence of an isostatic rebound in response to the almost complete desiccation of the Mediterranean Basin. If suddenly exposed to increased runoff and erosion of the northern Canigou flank during the peak of the MSC, the fault plane may have weakened resulting in the collapse and massive transport of destabilized rocks after the marine reflooding of the Mediterranean Basin. This event could be linked with the isostatic readjustements due to the rapid disappearance followed by the sudden return of marine water masses in the Mediterranean Basin.

Since the pioneer work by Norman and Chase (1986), the isostatic response to erosion and Mediterranean Sea unloading of the Messinian rivers, shelves and slopes has been quantified. Govers et al. (2009) modeled Krijgsman et al. (1999)'s scenario for the MSC in which most of the evaporite load was deposited during a highstand sea level, followed by rapid desiccation. In this model, the evaporite load is added to water mass during the highstand but is balanced by the unload caused by evaporation during the desiccation phase. The resulting vertical deformation is of hundreds of meters: 
subsidence in central basins and uplift of the margins during the highstand with high depending on the regions, significant flexural uplift of the central basins, and subsidence of the margins during the desiccation step, followed by uplift at the regional scale after reflooding. In addition to its inexactitude, this scenario is in complete opposition with onshore and offshore observations in the Gulf of Lions area which support a fall in sea level at the beginning of the peak of the MSC and the deposition of central evaporites when the sea level rose before the catastrophic reflooding occurred (Bache et al., 2012). Accordingly, this model cannot be applied to the Canigou story. However, the case of the Messinian drawdown of the Black Sea, devoid of evaporites, is more applicable to the Canigou Massif with a realistic fall in the level of the Black Sea of $1800 \mathrm{~m}$ resulting in an uplift in the basin floor of $576 \mathrm{~m}$ and in the coastal land of 100-200 m (Bartol and Govers, 2009).

Gargani (2004) quantified the isostatic response of southern France lithosphere to a sea level drop of 1500 meters, proposed by Clauzon (1982). Gargani obtained an uplift of between 300 and $500 \mathrm{~m}$ for the basin and between 30 and $225 \mathrm{~m}$ for the coastal land. Significant sediment remobilization and erosion on Messinian shelves and slopes during the MSC increased the deposit volumes in the deep basin and trigger isostatic rebound. Based on geometric criteria in seismic stratigraphy, this rebound was measured on the Gulf of Lion outer shelf (Rabineau et al., 2014). The isostatic rebound reached $1.3 \mathrm{~km}$ in the Aude-Hérault outer shelf during the Messinian (i.e., 1.8 $\mathrm{km} / \mathrm{Myr}$, with a $0.7 \mathrm{Ma}$ duration for the crisis) and reactivated major faults inherited from the Oligocene rifting (Mauffret et al., 2001; Gorini et al., 2005). In these models, the isostatic response to marine reflooding has not been calculated.

In southern Calabria, whose paleogeography closely resembles that of the Roussillon - Canigou frame (i.e. a high relief close to the seashore) but in a context of lithospheric convergence, DeCelles and Cavazza (1995) calculated an uplift of around $1000 \mathrm{~m}$ and $200 \mathrm{~m}$ for the basin floor and the coastline, respectively, in response to a fall in sea level of $3400 \mathrm{~m}$, a more dramatic drop than usually accepted. In the similar paleogeographic relief of the Gibraltar Arc, a preliminary study by Silva et al. (2011) concluded that the (not quantified) most relevant relief production since the late Tortonian was attained just after the Messinian sea level drawdown. A similar study conducted in the same area (Silva et al., 2012) suggests that well-dated large scale avalanches of probable seismic origin followed the marine reflooding of the Mediterranean Basin, prepared by slope instability generated by the Messinian desiccation. These circumstances are precisely those that we imagine for the setting up of the Prades olistostrome.

We can thus affirm that the Messinian sea level drop and the subsequent reflooding may have significantly impacted the Canigou Massif through (1) increased exposure of the fault caused by uplift and (2) erosion of the soils caused by rivers and runoff during the desiccation phase, and (3) destabilization of its northern slope and huge collapses after marine refilling. This reconstruction contradicts Gunnell et al.'s assumption (2009), which states that the MSC had a minor impact in the Roussillon Basin and Eastern Pyrenees.

The destabilization of the Mediterranean margins related with the desiccation and reflooding events is documented offshore where large landslide masses were evidenced over the Messinian Erosional Surface (Gargani et al., 2014).

\section{Conclusion}


The Roussillon Basin, where a preliminary fluvial incision occurred during the Tortonian, was significantly impacted by erosion during the Messinian in relation with the dramatic drop in sea level at the peak of the MSC. In this study, the resulting MES was mapped (Supplementary data 1), thereby correcting some errors and omissions, and providing a promising outlook for three-dimensional reconstructions aimed at modernizing projects for geological mapping (Fig. 11). Depicting the MES on geological maps at any scale is a priority for the Mediterranean and adjacent regions, especially for industrial applications such as hydrocarbon exploration, hydrogeology, and the assessment of sand storage, etc.

Proximal Gilbert-type fan deltas document the sudden marine reflooding of the Mediterranean Basin, the marine-continental transition which marks the passage from prograding to aggrading sedimentation. Subsequently, the fluctuating global sea level controlled lateral and vertical environmental successions. Thanks to the comparison of independent datings (planktonic foraminifers, calcareous nannofossils, micro-macromammals, paleomagnetism, ${ }^{10} \mathrm{Be}$ cosmogenic nuclide-derived studies), we were able do describe the consistent evolution of the Roussillon Basin from 6 to $3 \mathrm{Ma}$ (Fig. 18), in which sea level changes and subsidence appear to have played major roles.

At the foot of the Mount Canigou, the Prades olistostrome (inside the Early Pliocene deposits) documents a local but impressive event that we link to the MSC isostatic readjustments. It actually appears to have been caused by the dramatic drop in sea level in the latest Messinian, which (1) exposed the Canigou fault and uplifted the massif (desiccation phase) and (2) collapsed the destabilized mass (after marine reflooding) (Fig. 20). Our results also provide information on the palaeo-altitudinal evolution of the Mount Canigou.

To conclude, the MSC is a striking episode, independent of the Pyrenean orogenesis, which, if one is guided by an objective examination, had significant consequences. The Roussillon Basin is confirmed here as a reference for Mediterranean non-silled peripheral basins, i.e. devoid of evaporites, strongly impacted by the peak of the MSC and subsequent marine reflooding.

\section{Acknowledgments}

A large part of this paper is the result of geological mapping by the late Georges Clauzon at the request of the French Geological Survey (B.R.G.M.) which, ultimately did not accept his interpretation of the Messinian Erosional Surface despite its international validation by the main protagonists in the framework of the "Consensus" published by the CIESM in 2008 (Commission Internationale d'Etude Scientifique de la Méditerranée). Cédric Duvail's PhD thesis (University Montpellier 2) was supported by a grant from the Languedoc-Roussillon Region and B.R.G.M. (SYSCOLAG Project). David Besson's internship was financed by the Regional Survey of the B.R.G.M. (Montpellier). The INSU - TOTAL - I.F.R.E.M.E.R. B.R.G.M. programs GDR Marges and subsequently Actions Marges (MEDOCC: Variations of the Pliocene sea level in the Mediterranean) contributed to the financing of this work, particularly in the form of grants for some of the field trips. This paper is a contribution to the ANR 'PYRAMID' Project. We are grateful to the ASTER Team (D.L. Bourlès, L. Léanni, M. Arnold, G. Aumaitre and K. Keddadouche) for their valuable assistance during ${ }^{10} \mathrm{Be}$ measurements at the ASTER AMS national facility (CEREGE, Aix en Provence), which is supported by the INSU/CNRS, the ANR through the "Projets thématiques d'excellence" program for "Equipements d'excellence" ASTER-CEREGE action, IRD and CEA. The Digital Elevation Model, 
provided by ASTER GDEM and used for the modeling process, is a product of METI and NASA. This manuscript benefited from comments by two anonymous referees. Daphne Goodfellow edited the English of the manuscript.

\section{References}

Aguilar, J.-P., 1977. Données nouvelles sur l'âge des formations lacustres des bassins de Narbonne - Sigean et de Leucate (Aude) à l'aide des micromammifères. Geobios 10(4), 643-645.

Aguilar, J.-P., Legendre, S., Michaux, J., Montuire, S., 1999. Pliocene mammals and cliamtic reconstruction in the Western Mediterranean area. In: Wrenn, J.H., Suc, J.P., Leroy, S.A.G. (Eds.), The Pliocene: Time of Change, Amer. Assoc. Stratigr. Palynologists Foundation, pp. 109-120.

Aguilar, J.-P., Magné, J., 1978. Nouveaux gisements à Rongeurs dans des formations marines miocènes du Languedoc méditerranéen. Bull. Soc. Géol. France 20(6), ser. 7, 803-805.

Aunay, B., Duvail, C., Giordana, G., Le Strat, P., Montginoul, M., Pistre, S., 2006. A pluridisciplinary methodology for integrated management of a coastal aquifer. Geological, hydrogeological and economic studies of the Roussillon aquifer (Pyrénées-Orientales, France). Life and environment 56(4), 275-285.

Babault, J., Van den Driessche, J., Bonnet, S., Castelltort, S., Crave, A., 2005. Origin of the highly elevated Pyrenean peneplain. Tectonics 24, TC2010, doi:10.1029/2004TC001697.

Babault, J., Van den Driessche, J., Bonnet, S., Castelltort, S., Crave, A., 2006. Reply to comment by Yanni Gunnell and Marc Calvet on "Origin of the highly elevated Pyrenean peneplain”. Tectonics 25, TC3004, doi:10.1029/2005TC001922.

Bache, F., Olivet, J.-L., Gorini, F., Rabineau, M., Baztan, J., Aslanian, D., Suc, J.-P., 2009. Messinian Erosional and Salinity Crises: View from the Provence Basin (Gulf of Lions, Western Mediterranean). Earth Planet. Sci. Lett. 286, 139-157.

Bache, F., Popescu, S.-M., Rabineau, M., Gorini, C., Suc, J.-P., Clauzon, G., Olivet, J.-L., Rubino, J.-L., Melinte-Dobrinescu, M.C., Estrada, F., Londeix, L., Armijo, R., Meyer, B., Jolivet, L., Jouannic, G., Leroux, E., Aslanian, D., Dos Reis, A.T., Mocochain, L., Dumurdžanov, N., Zagorchev, I., Lesić, V., Tomić, D., Çağatay, M.N., Brun, J.-P., Sokoutis, D., Csato, I., Ucarkus, G., Çakir, Z., 2012. A two-step process for the reflooding of the Mediterranean after the Messinian Salinity Crisis. Bas. Res. 24,125-153.

Bandet, Y., 1975. Les terrains néogènes du Conflent et du Roussillon nord occidental (PhD Thesis). University of Toulouse, p. 56.

Bartol, J., Govers, R., 2009. Flexure due to the Messinian-Pontian sea level drop in the Black Sea. Geochem. Geophys. Geosyst. 10(10), Q10013, doi:10.1029/2009GC002672, 14 pp.

Baudelot, S., Crouzel, F., 1974. La faune burdigalienne des gisements d'Espira-duConflent (Pyrénées-Orientales). Bull. Soc. Hist. Nat. Toulouse 110(3-4), 311-326.

Beaudouin, C., Suc, J.-P., Escarguel, G., Arnaud, M., Charmasson, S., 2007. The significance of pollen signal in present-day marine terrigenous sediments: The example of the Gulf of Lions (western Mediterranean Sea). Geobios 40, 159-172. 
Berger, G.-M., Aloïsi, J.-C., Got, H., Marchal, J.-P., Martin, R., Michaux, J., Monaco, A., 1982. Leucate. Carte géologique de la France à 1/50000, 1079, B.R.G.M. (Ed).

Berger, G.M., Fonteilles, M., Leblanc, D., Clauzon, G., Marchal, J.P., Vautrelle, C., 1993. Rivesaltes. Carte géologique de la France à 1/50000, 1090, B.R.G.M. (Ed).

Bierman, P., Steig, E.G., 1996. Estimating denudation using cosmogenic isotope abundances in sediment. Earth Surf. Process. Landforms 21, 125-139.

Bourcart, J., 1945. Etude des sédiments pliocènes et quaternaires du Roussillon. Bull. Serv. Carte Géol. France 218(45), 395-476.

Brown, E.T., Stallard, R.F., Larsen, M.C., Raisbeck, G.M., Yiou, F., 1995. Denudation rates determined from the accumulation of in situ-produced $10 \mathrm{Be}$ in the Luquillo Experimental Forest, Puerto Rico. Earth Planet. Sci. Lett. 129, 193-202.

Calcagno, P., Chilès, J.P., Courrioux, G., Guillen, A., 2008. Geological modelling from field data and geological knowledge: Part I. Modelling method coupling 3D potential-field interpolation and geological rules. Phys. Earth Planet. Interiors 171, 147-157.

Calvet, M., 1996. Morphogenèse d'une montagne méditerranéenne, les Pyrénées orientales. Doc. Bur. Rech. Géol. Min. 255, 1177 p.

Calvet, M., Gunnell, Y., 2008. Planar landforms as markers of denudation chronology: an inversion of East Pyrenean tectonics based on landscape and sedimentary basin analysis. In: Gallagher, K., Jones, S.J., Wainwright, J. (Eds.), Landscape Evolution: Denudation, Climate and tectonics Over Different Time and Space Scales. Geol. Soc. London, Spec. Publ. 296, pp. 147-166.

Chantraine, J., Chêne, F., Nehlig, P., Rabu, D., 2005. Carte géologique de la France à $1 / 10000006^{\mathrm{e}}$ édition révision 2003 - Fourniture des données numériques (Notice d'utilisation), BRGM/RP-54298-FR, 52 pp.

CIESM (Antón, J., Çağatay, M.N., De Lange, G., Flecker, R., Gaullier, V., GundeCimerman, N., Hübscher, C., Krijgsman, W., Lambregts, P., Lofi, J., Lugli, S., Manzi, V., McGenity, T.J., Roveri, M., Sierro, F.J., Suc J.-P.), 2008. Executive Summary. In: Briand, F. (Ed.), The Messinian Salinity Crisis from mega-deposits to microbiology - A consensus report. CIESM Workshop Monographs 33, pp. 7-28.

Clauzon, G., 1978. The Messinian Var canyon (Provence, Southern France) Paleogeographic implications. Mar. Geol. 27, 231-246.

Clauzon, G., 1979. Le canyon messinien de la Durance (Provence, France): Une preuve paléogéographique du bassin profond de dessiccation. Palaeogeogr., Palaeoclimatol., Palaeoecol. 29, 15-40.

Clauzon, G., 1982. Le canyon messinien du Rhône : une preuve décisive du "dessicated deep-basin model" (Hsü, Cita et Ryan, 1973). Bull. Soc. Géol. France 24, 597-610.

Clauzon, G., 1987. Le détritisme néogène du bassin du Roussillon (PyrénéesOrientales, France). Géol. Alpine 13, 427-441.

Clauzon, G., 1990. Restitution de l'évolution géodynamique néogène du bassin $\mathrm{du}$ Roussillon et de l'unité adjacente des Corbières d'après les données écostratigraphiques et paléogéographiques. Paleobiol. cont. 17, 125-155.

Clauzon, G., 1996. Limites de séquences et évolution géodynamique. Géomorphologie $1,3-22$.

Clauzon, G., Aguilar, J.-P., Michaux, J., 1987. Le bassin pliocène du Roussillon (Pyrénées orientales, France): exemple d'évolution géodynamique d'une ria méditerranéenne consécutive à la crise de salinité messinienne. C. R. Acad. Sci. Paris Ser. 2, 304, 585-590. 
Clauzon, G., Berger, G., Aloisi, J.-C., Marchal, J.-P., Monaco, A., Got, H., Augris, C., Michaux, J., Suc, J.-P., Gadel, F., Martin-Buscail, R., 1989. Perpignan. Carte géologique de la France à 1/50000, 1091, B.R.G.M. (Ed).

Clauzon, G., Cravatte, J., 1985. Révision chronostratigraphique de la série marine pliocène traversée par le sondage Canet 1 (Pyrénées-orientales): apports à la connaissance du Néogène du Roussillon. C. R. Acad. Sci. Paris Ser. 2, 301, 13511354.

Clauzon, G., Rubino, J.-L., 2001. La Crise de salinité messinienne et les Gilbert deltas pliocènes marqueurs de l'évolution géodynamique du Roussillon et du Conflent. Guide-book of the fieldtrip of the GDR Marges, CEREGE and Provence University, Aix en Provence, Total Fina Elf, Pau, 25 pp. Figures available at: http://www.alganapa.com/\#! patrimoine-geologique-clauzon/c1x9v.

Clauzon, G., Suc, J.-P., Aguilar, J.-P., Ambert, P., Cappetta, H., Cravatte, J., Drivaliari, A., Doménech, R., Dubar, M., Leroy, S., Martinell, J., Michaux, J., Roiron, P., Rubino, J.-L., Savoye, B., Vernet, J.-L., 1990. Pliocene geodynamic and climatic evolutions in the French Mediterranean region. Paleontol. Evol. spec. issue 2, 132-186.

Clauzon, G., Suc, J.-P., Gautier, F., Berger, A., Loutre, M.-F., 1996. Alternate interpretation of the Messinian salinity crisis: Controversy resolved? Geology 24(4), 363-1366.

Clauzon, G., Suc, J.-P., Do Couto, D., Jouannic, G., Melinte-Dobrinescu, M.C., Jolivet, L., Quillévéré, F., Lebret, N., Mocochain, L., Popescu, S.-M., Martinell, J., Doménech, R., Rubino, J.-L., Gumiaux, C., Warny, S., Bellas, S.M., Gorini, C., Bache, F., Rabineau, M., Estrada, F., 2015. New insights on the Sorbas Basin (SE Spain): the onshore reference of the Messinian Salinity Crisis. Mar. Petrol. Geol., doi:10.1016/j.marpetgeo.2015.02.016.

Cox, C.B., 1952. Etude sismique réflexion - Roussillon, Argelès. Report of the General Geophysical Company of France for the Compagnie d'Exploration Pétrolière, $24 \mathrm{pp}$.

Cravatte, J., Dufaure, P., Prim, M., Rouaix, S., 1974. Les sondages du Golfe du Lion: stratigraphie et sédimentologie. Notes Mém. Comp. Fr. Pétroles 2, 209-274.

Cravatte, J., Matias, I., Suc, J.-P., 1984. Nouvelles recherches biostratigraphiques sur le Pliocène du Roussillon. Géol. France 1-2, 149-163.

Cravatte, J., Suc, J.-P., 1981. Climatic evolution of North-Western Mediterranean area during Pliocene and Early Pleistocene by pollen-analysis and forams of drill Autan 1. Chronostratigraphic correlations. Pollen et Spores 23(2) 247-258.

DeCelles, P.G., Cavazza, W., 1995. Upper Messinian conglomerates in Calabria, southern Italy: Response to orogenic wedge adjustment following Mediterranean sea-level changes. Geology 23(9), 775-778.

Depéret, C., 1885. Description géologique du bassin tertiaire du Roussillon. Masson (Ed.), Paris, p. 274.

Depéret, C., 1890-97. Les animaux pliocènes du Roussillon. Mém. Soc. Géol. France 3, p. 194.

Do Couto, D., Gumiaux, C., Jolivet, L., Augier, R., Lebret, N., Folcher, N., Jouannic, G., Suc, J.-P., Gorini, C., 2015. 3D modelling of the Sorbas basin (Spain): New constraints on the Messinian Erosional Surface morphology. Mar. Petrol. Geol., doi:10.1016/j.marpetgeo.2014.12.011.

Do Couto, D., Popescu, S.-M., Suc, J.-P., Melinte-Dobrinescu, M.C., Barhoun, N., Gorini, C., Jolivet, L., Poort, J., Jouannic, G., Auxietre, J.-L., 2014. Lago Mare and 
the Messinian Salinity Crisis: Evidences from the Alboran Sea (S. Spain). Mar. Petrol. Geol. 52, 57-76.

Donzeau, M., Laumonier, B., Guitard, G., Autran, A., Llac, F., Baudin, T., Calvet, M., 2010. Céret. Carte géologique de la France à 1/50000, 1096, published online, B.R.G.M. (Ed).

Dunaï, T., 2010. Cosmogenic nuclides: principles, concepts and applications in the earth surface sciences. Cambridge University Press, p. 187.

Duvail C., 2008. Expression des facteurs régionaux et locaux dans l'enregistrement sédimentaire d'une marge passive. Exemple de la marge du Golfe du Lion étudiée selon un continuum terre-mer (PhD Thesis). University Montpellier 2, p. 296. https://tel.archives-ouvertes.fr/file/index/docid/438146/filename/theseduvail.pdf.

Duvail, C., Gorini, C., Lofi, J., Le Strat, P., Clauzon, G., Dos Reis, A.T., 2005. Correlation between onshore and offshore Pliocene-Quaternary systems tracts below the Roussillon Basin (eastern Pyrenees, France). Mar. Petrol. Geol. 22, 747-756.

Duvail, C., Le Strat, P., 2002. Architecture et géométrie haute résolution des prismes sédimentaires plio-quaternaires au droit du Roussillon suivant un profil terre-mer. Report BRGM/RP-51972-FR, 70 pp.

Duvail, C., Le Strat, P., Alabouvette, B., Perrin, J., Seranne, M., 2000. Evolution géodynamique du bassin du Roussillon: Analyse des profils sismiques calibrés par les sondages profonds de Elne 1 et de Canet 1. Report GTR/BRGM/1200-137, 23 pp.

Fontannes, F., 1879-82. Les mollusques pliocènes de la vallée du Rhône et du Roussillon (gastéropodes et bivalves). Savy (Ed.), Paris, p. 586.

Furon, R., 1940. Observations préliminaires sur la région située au Nord du Canigou (Pyrénées orientales). C. R. somm. Soc. Géol. France Ser. 5, 10, 43-45.

Gargani, J., 2004. Modelling of the erosion in the Rhône valley during the Messinian crisis (France). Quat. Intern. 121, 13-22.

Gargani, J., Bache, F., Jouannic, G., Gorini, C., 2014. Slope destabilization during the Messinian Salinity Crisis. Geomorphology 213, 128-138.

Gennesseaux, M., Lefebvre, D., 1980. Le Golfe du Lion et le Paléo-Rhône messinien. Géol. Méd. 7, 71-80.

Gilbert, G.K., 1885. The topographic features of lake shores. U.S. Geol. Surv. Rep. 5, 75-123.

Gilbert, G.K., 1890. Lake Bonneville. Monogr. U.S. Geol. Surv. 1, p. 438.

Gorini, C., 1994. Géodynamique d'une marge passive: le Golfe du Lion (Méditerranée occidentale) ( $\mathrm{PhD}$ Thesis). Univ. P. Sabatier, Toulouse 1, p. 256.

Gorini, C., Haq, B.U., Reis, A.T. dos, Silva, C.G., Cruz, A., Soares, E., Grangeon, D., 2014. Late Neogene sequence stratigraphic evolution of the Foz do Amazonas Basin, Brazil. Terra Nova 26, 179-185.

Gorini, C., Lofi, J., Duvail, C., Dos Reis, A.T., Guennoc, P., Le Strat, P., Mauffret, A., 2005. The Late Messinian salinity crisis and late Miocene tectonism: Interaction and consequences on the physiography and post-rift evolution of the Gulf of Lions margin. Mar. Petrol. Geol. 22, 695-712.

Gottis, M., 1958. L'apport des travaux de la Compagnie d'exploration pétrolière (C.E.P.) dans la connaissance du bassin tertiaire du Roussillon. Bull. Soc. Géol. France Ser. 6, 8(8), 881-883.

Gosse, J.C., Phillips, F.M., 2001. Terrestrial in situ cosmogenic nuclides: theory and application. Quat. Sci. Rev. 20, 1475-1560.

Govers, R., Meijer, P., Krijgsman, W., 2009. Regional isostatic response to Messinian Salinity Crisis events. Tectonophysics 463, 109-129. 
Granger, D.E., Kirchner, J.W., Finkel, R., 1996. Spatially-averaged long-term erosion rates measured from in situ-produced cosmogenic nuclides in alluvial sediment. Journ. Geol. 104, 249-257.

Guennoc, P., Debeglia, N., Gorini, C., Le Marrec, A., Mauffret, A., 1994. Anatomie d'une marge passive jeune (Golfe du Lion - Sud France): Apports des données géophysiques. Bull. Centres Rech. Explor.-Prod. Elf Aquitaine 18(1), 33-57.

Guennoc, P., Gorini, C., Mauffret, A., 2000. Histoire géologique du golfe du Lion et cartographie du rift oligo-aquitanien et de la surface messinienne. Géol. France 3, 67-97.

Guérin, C., 1975. Les rhinocéros (Mammalia, Perissodactyla) des gisements pliocènes français: intérêt biostratigraphique et paléoécologique. Coll. intern. C.N.R.S. 218, pp. 739-747.

Guérin, C., 1982. Les Rhinocerotidae (Mammalia, Perissodactyla) du Miocène terminal au Pléistocène supérieur d'Europe occidentale comparés aux espèces actuelles: tendances évolutives et relations phylogénétiques. Geobios 15(4), 599605.

Guillen, A., Calcagno, P., Courrioux, G., Joly, A., Ledru, P., 2008. Geological modeling from field data and geological knowledge: Part II. Modeling validation using gravity and magnetic data inversion. Phys. Earth Planet. Interiors 171, 158169.

Guitard, G., Laumonier, B., Autran, A., Bandet, Y., Berger, G.M., 1998. Prades. Carte géologique de la France à 1/50000, 1095, B.R.G.M. (Ed).

Gunnell, Y., Calvet, M., 2006. Comment on "Origin of the highly elevated Pyrenean peneplain" by Julien Babault, Jean Van Den Driessche and Stéphane Bonnet, Sébastien Castelltort, and Alain Crave. Tectonics 25, TC3003, doi:10.1029/2005TC001849.

Gunnell, Y., Calvet, M., Brichau, S., Carter, A., Aguilar, J.-P., Zeyen, H., 2009. Low long-term erosion rates in high-energy mountain belts: Insights from thermo- and biochronology in the Eastern Pyrenees. Earth Planet. Sci. Lett. 278(3-4), 208-218.

Gunnell, Y., Zeyen, H., Calvet, M., 2008. Geophysical evidence of a missing lithospheric root beneath the Eastern Pyrenees: Consequences for post-orogenic uplift and associated geomorphic signatures. Earth Planet. Sci. Lett. 276, 302-313.

Haq, B., Hardenbol, J., Vail, P.R., 1987. Chronology of Fluctuating Sea levels Since the Triassic. Science 235, 1156-1167.

Huard, M., Pelissonnier, H., 1969. Tectonique pliocène à la bordure nord du massif du Canigou (Pyrénées orientales). C.R. Acad. Sci. Paris Ser. D, 269, 127-130.

Krijgsman, W., Hilgen, F.J., Raffi, I., Sierro, F.J., Wilson, D.S., 1999. Chronology, causes and progression of the Messinian salinity crisis. Nature 400, 652-655.

Leroux, E., 2012. Quantification des flux sédimentaires et de la subsidence du bassin Provençal (PhD Thesis). Brest University, p. 455.

Le Strat, P., Duvail, C., 2008. Contribution à la connaissance du Tortono-Messinien sur le pourtour du Golfe du Lion. Séance spéc., Soc. Géol. France, pp. 46.

Le Strat, P., Duvail, C., Clauzon, G., 2001. Présentation des travaux de cartographie du B.R.G.M. en Roussillon depuis 1996. Workshop "Messinien dans le Golfe du Lion", GDR Marges, Perpignan.

Lindsay, E.H., 1985. European late Cenozoic biochronology and the magnetic polarity time scale. Nat. Geogr. Soc. Res. Rep. 1985 Projects, pp. 449-456.

Lofi, J., Déverchère, J., Gaullier, V., Gillet, H., Gorini, C., Guennoc, P., Loncke, L., Maillard, A., Sage, F., Thinon, I., 2011. Atlas of the "Messinian Salinity Crisis" 
seismic markers in the Mediterranean and Black seas. Comm. Geol. Map of the World and Soc. Géol. France, p. 73.

Lofi, J., Gorini, C., Berné, S., Clauzon, G., Dos Reis, A.T., Ryan, W.B.F., Steckler, M.S., 2005. Erosional processes and paleo-environmental changes in the Western Gulf of Lions (SW France) during the Messinian Salinity Crisis. Mar. Geol. 217, 130.

Lofi, J., Rabineau, M., Gorini, C., Berne, S., Clauzon, G., De Clarens, P., Dos Reis, A.T., Mountain, G.S., Ryan, W.B.F., Steckler, M.S., Fouchet, C., 2003. PlioQuaternary prograding clinoform wedges of the western Gulf of Lion continental margin (NW Mediterranean) after the Messinian Salinity Crisis. Mar. Geol. 198, 289-317.

Loget, N., Van Den Driessche, J., Davy, P., 2005. How did the Messinian Salinity Crisis end? Terra Nova 17, 414-419.

Lourens, L.J., Hilgen, F.J., Laskar, J., Shackleton, N.J., Wilson, D., 2005. The Neogene period. In: Gradstein, F.M., Ogg, J.G., Smith, A.G. (Eds.), A geological Time Scale 2004. Cambridge University Press, Cambridge, pp. 409-440.

Martinell, J., Doménech, R., 1984. Données nouvelles sur la malacofaune du Pliocène marin de la vallée de la Têt, aux environs de Millas (Pyrénées-Orientales). Géol. France 1-2, 165-174.

Martinell, J., Doménech, R., 1990. Malacofaune du Pliocène marin du Roussillon: taphonomie et paléoécologie. Paléobiol. cont. 17, 157-166.

Mauffret, A., Durand de Grossouvre, B., Dos Reis, A.T., Gorini, C., Nercessian, A., 2001. Structural geometry in the eastern Pyrenees and western Gulf of Lion (Western Mediterranean). Journ. Struct. Geol. 23(11), 1701-1726.

Mein, P., Aymar, J., 1984. Découvertes récentes de mammifères dans le Pliocène du Roussillon. Note préliminaire. Nouv. Arch. Mus. Hist. Nat. Lyon 22, suppl., 69-71.

Melinte-Dobrinescu, M.C., Suc, J.-P., Clauzon, G., Popescu, S.-M., Armijo, R., Meyer, B., Biltekin, D., Çağatay, M.N., Ucarkus, G., Jouannic, G., Fauquette, S., Çakir, Z., 2009. The Messinian Salinity Crisis in the Dardanelles region: Chronostratigraphic constraints. Palaeogeogr., Palaeoclimatol., Palaeoecol. 278, 24-39.

Michaux, J., 1976. Découverte d'une faune de petits Mammifères dans le Pliocène continental de la vallée de la Canterrane (Roussillon); ses conséquences stratigraphiques. Bull. Soc. géol. France Ser. 7, 18(1), 165-170.

Miller, K.G., Mountain, G.S., Wright, J.D., Browning, J.V., 2011. A 180-million-year record of sea level and ice volume cariations from continental margin and deep-sea isotopic records. Oceanography 24(2), 40-53.

Molliex, S., Rabineau, M., Leroux, E., Aslanian, D., Chauvet, F., Bourlès, D., Révillon, S., Jouët, G., 2012. Geomorphological feedback between watershed erosion and marine sedimentation in the Gulf of Lion margin (SE France). EGU General Assembly, 22-27 April 2012, Vienna, vol.14, 12692.

Norman, S.E., Chase, C.G., 1986. Uplift of the shores of the western Mediterranean due to Messinian desiccation and flexural isostasy. Nature 322, 450-451.

Oele, E., Sluitter, W.J., Pannekoek, A.J., 1963. Tertiary and Quaternary sedimentation in the Conflent: an intramontane rift-Valley in the eastern Pyrenees. Leidse Geol. Meded. D 28, 297-319.

Pannekoek, A.J., 1935. Evolution du bassin de la Têt pendant le Néogène. Geogr. Geol. Mad. Rijkuniv. Utrecht 10, p. 72.

Popescu, S.-M., Biltekin, D., Winter, H., Suc, J.-P., Melinte-Dobrinescu, M.C., Klotz, S., Combourieu-Nebout, N., Rabineau, M., Clauzon, G., Deaconu, F., 2010. 
Pliocene and Lower Pleistocene vegetation and climate changes at the European scale: Long pollen records and climatostratigraphy. Quat. Intern. 219, 152-167.

Rabineau, M., Leroux, E., Aslanian, D., Bache, F., Gorini, C., Moulin, M., Molliex, S., Droz, L., dos Reis, A.T., Rubino, J.-L., Guillocheau, F., Olivet, J.-L., 2014. Quantifying subsidence and isostatic readjustment using sedimentary paleomarkers, example from the Gulf of Lion. Earth Planet. Sci. Lett. 388, 353-366.

Roveri, M., Flecker, R., Krijgsman, W., Lofi, J., Lugli, S., Manzi, V., Sierro, F.J., Bertini, A., Camerlenghi, A., De Lange, G., Govers, R., Hilgen, F.J., Hübscher, C., Meijer, P.Th., Stoica, M., 2014a. The Messinian Salinity Crisis: Past and future of a great challenge for marine sciences. Mar. Geol. 352, 25-58.

Roveri, M., Gennari, R., Lugli, S., Manzi, V., 2009. The Terminal Carbonate Complex: the record of sea-level changes during the Messinian salinity crisis. GeoActa 8, 63-77.

Roveri, M., Manzi, V., Bergamasco,, A., Falcieri, F.M., Gennari, R., Lugli, S., Schreiber, B.C., 2014b. Dense shelf water cascading and Messinian canyons: A new scenario for the Mediterranean Salinity Crisis. Amer. J. Sci. 314, 751-784.

Ryan, W.B.F., Cita, M.B., 1978. The nature and distribution of Messinian erosional surface-indication of a several kilometer-deep Mediterranean in the Miocene. Mar. Geol. 27, 193-230.

Schlupp, A., Clauzon, G., Avouac, J.-P., 2001. Mouvement post-messinien sur la faille de Nîmes: implications pour la sismotectonique de la Provence. Bull. Soc. géol. France 172(6), 697-711.

Silva, P.G., Huerta, P., Elez, J., Civis, J., Perucha, M.Á., Zazo, C., Goy, J.L., Dabrio, C.J., Bardají,T., 2012. The Zanclean flooding in the Gibraltar arc (South Spain): Proxy data on Pliocene induced seismicity by the Meditrranean Sea refilling. $3^{\text {rd }}$ INQUA - IGCP-567 Intern. Workshop on "Active Tectonics, Paleoseismology and Archaeoseismology", Morelia, Mexico, pp. 169-173.

Silva, P.G., Ribó, A., Bentacor, M.M., Huerta, P., Perucha, M.Á., Zazo, C., Goy, J.L., Dabrio, C.J., Bardají,T., 2011. Relief production, uplift and active tectonics in the Gibraltar Arc (South Spain) from the late Tortonian to the Present. $2^{\text {nd }}$ INQUA IGCP-567 Intern. Workshop on "Active Tectonics, Earthquake Geology, Archaeology and Engineering", Corinth, Greece, pp. 227-230.

Suc, J.-P., 1976. Apports de la palynologie à la connaissance du Pliocène du Roussillon (sud de la France). Geobios 9(6), 741-771.

Suc, J.-P., 1984. Origin and evolution of the Mediterranean vegetation and climate in Europe. Nature 307, 429-432.

Suc, J.-P., Diniz, F., Leroy, S., Poumot, C., Bertini, A., Dupont, L., Clet, M., Bessais, E., Zheng, Z., Fauquette, S., Ferrier, J., 1995b. Zanclean ( Brunssumian) to early Piacenzian ( early-middle Reuverian) climate from $4^{\circ}$ to $54^{\circ}$ north latitude (West Africa, West Europe and West Mediterranean areas). Meded. Rijks Geol. Dienst 52, 43-56.

Suc, J.-P., Fauquette, S., 2012. The use of pollen floras as a tool to estimate palaeoaltitude of mountains: The eastern Pyrenees in the Late Neogene, a case study. Palaeogeogr., Palaeoclimatol., Palaeoecol. 321-322, 41-54.

Suc, J.-P., Violanti, D., Londeix, L., Poumot, C., Robert, C., Clauzon, G., Turon, J.-L., Ferrier, J., Chikhi, H., Cambon, G., Gautier, F., 1995a. Evolution of the Messinian Mediterranean environments: the Tripoli Formation at Capodarso (Sicily, Italy). Rev. Palaeobot. Palynol. 87, 51-79. 
von Blanckenburg, F., 2005. The control mechanisms of erosion and weathering at basin scale from cosmogenic nuclides in river sediment. Earth Planet. Sci. Lett. 237(3-4), 462-479.

Welsh, K.L.M., 1954. Etude de sismique réflexion pour la Société Nationale des Pétroles du Languedoc méditerranéen. Report of the Compagnie française de Prospection sismique, p. 31.

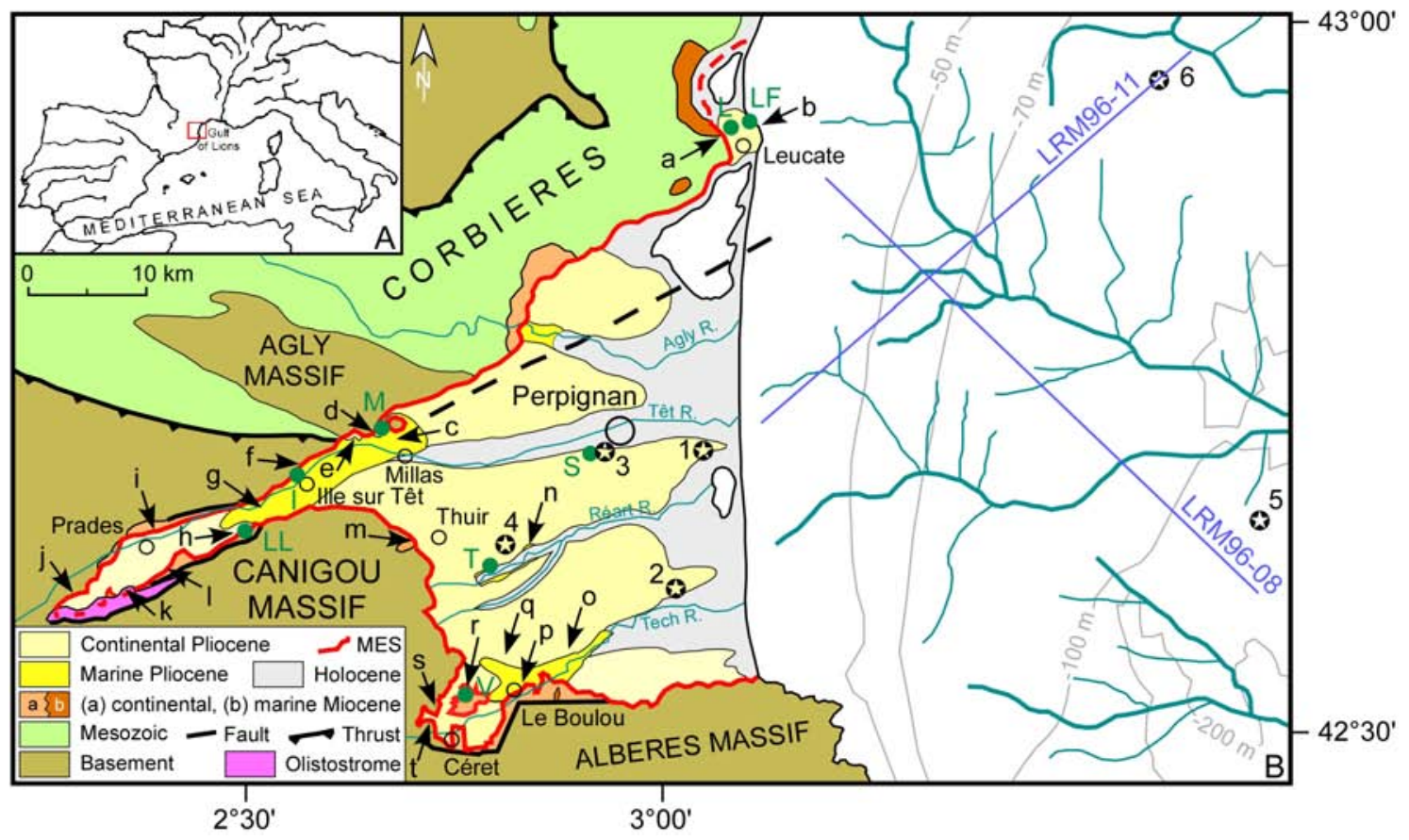

Fig. 1. The Roussillon Basin.

A, Map in the Western Mediterranean region.

B, Simplified geological map of the Roussillon Basin showing the location of the offshore seismic profiles LRM96-08 and LRM96-11 and reconstructed Messinian fluvial network according to Lofi et al. (2003, 2005), Gorini et al. (2005) and Bache et al. (2009, 2012).

Long wells used in this paper: 1, Canet 1; 2, Elne 1; 3, Mutualité agricole F1; 4, Ponteilla; 5, Rascasse 1; 6, Tramontane 1.

Selection of sections studied: a, Codequas (Leucate); b, Trois Frères Cape (La Franqui); c, Saint-Martin (Millas); d, Poc Calbeil (Néfiach); e, Bente Farine (Néfiach); f, Les Orgues (Ille sur Têt); g, Les Escoumes (Vinça); h, La Lentilla (Marquixanes); i, Montcamill (Catlar); j, Coma del Mas (Serdinya); k, Saint-Eusèbe pass; 1, Villerach; m, Rigall (Thuir); n, Ribèral (Trouillas); o, Les Forques (Banyuls dels Aspres); p, Moli Nou (Le Boulou); q, Pla del Rey (Tresserre) ; r, Els Pontells (Vivès); s, Mas Tauriac (Céret); t, Sant Pau chapel (Céret).

Localities with mammal fauna: LL, La Lentilla; V, Vivès 2; M, Millas; I, Ille sur Têt; T, Terrats; S, Serrat d'en Vacquer; L, Leucate; LF, La Franqui. MES, Messinian Erosional Surface. 

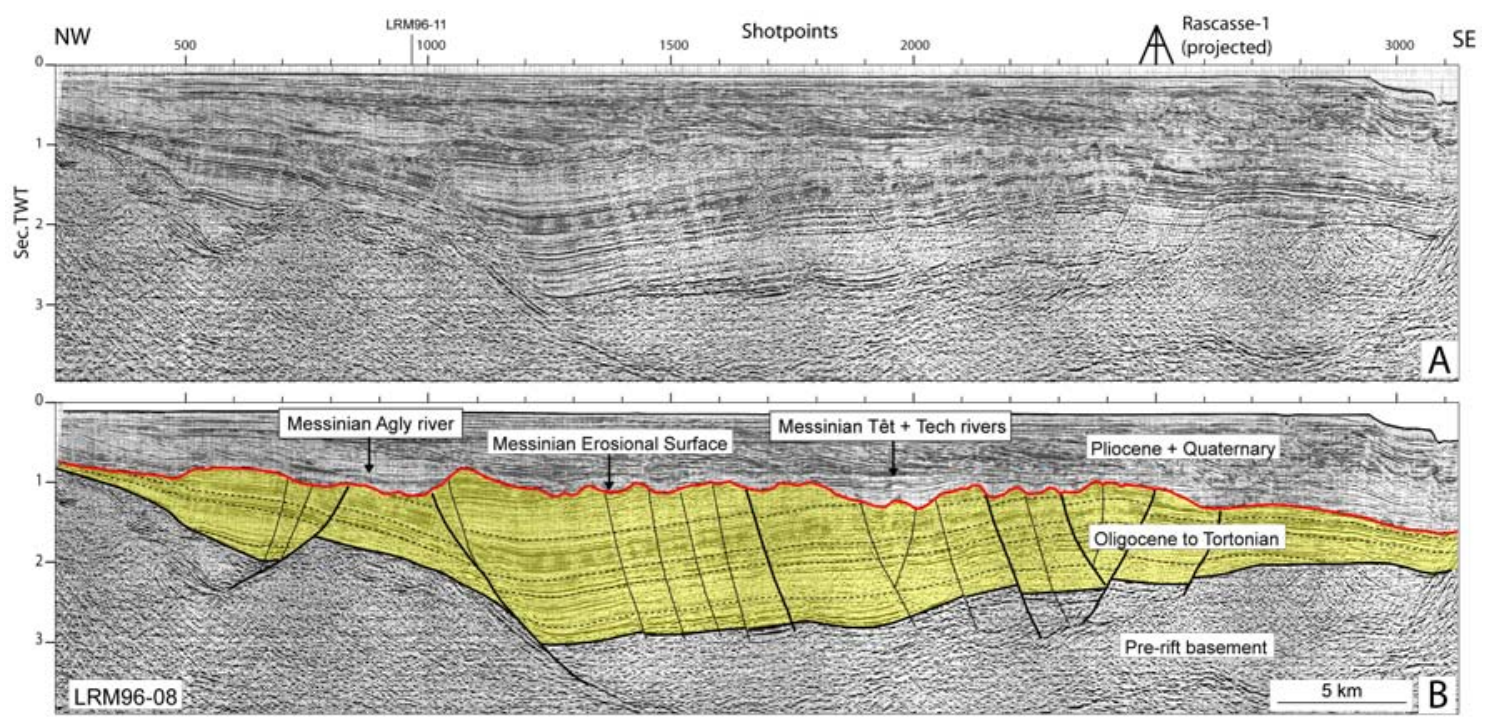

Fig. 2. Interpreted and uninterpreted seismic profile LRM96-08 across the Gulf of Lions showing the unconformity that erodes faulted and relatively parallel strata. Mapping of this unconformity revealed a pattern of up to $5^{\text {th }}$ order dendritic drainage with two main systems (Fig. 1) (Genesseaux and Lefebvre, 1980; Guennoc et al., 2000; Lofi et al., 2005; Bache et al., 2009). The two systems were mapped upstream in the Languedoc-Roussillon region and in the Rhône Valley where erosion is observed up to at least $350 \mathrm{~km}$ from the present coast (Clauzon, 1978, 1979, 1982). This unconformity is commonly interpreted as a subaerial erosional surface (the Messinian Erosional Surface) sculpted during the main MSC fall in sea level (Ryan and Cita, 1978; Guennoc et al., 2000; Lofi et al., 2005; Bache et al., 2009). The location of the seismic profile is shown in Figure 1.

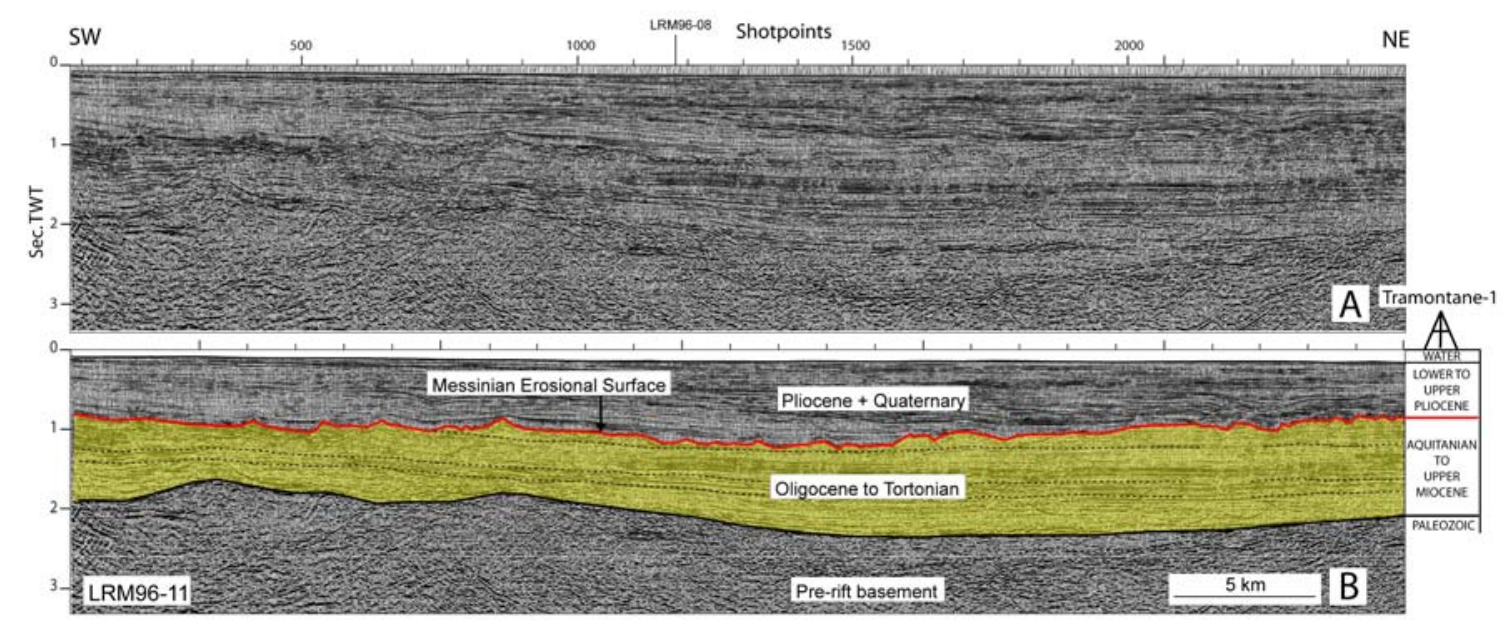

Fig. 3. Interpreted and uninterpreted seismic profile LRM96-11 across the Gulf of Lions tied to Tramontane-1 well. The erosional surface observed offshore Roussillon truncates Upper Miocene sediments and is covered by sediments from the earliest stage of the Pliocene (Cravatte et al., 1974; Guennoc et al., 2000) supporting the hypothesis that this unconformity corresponds to the Messinian Erosional Surface. The location of the seismic profile is shown in Figure 1. 

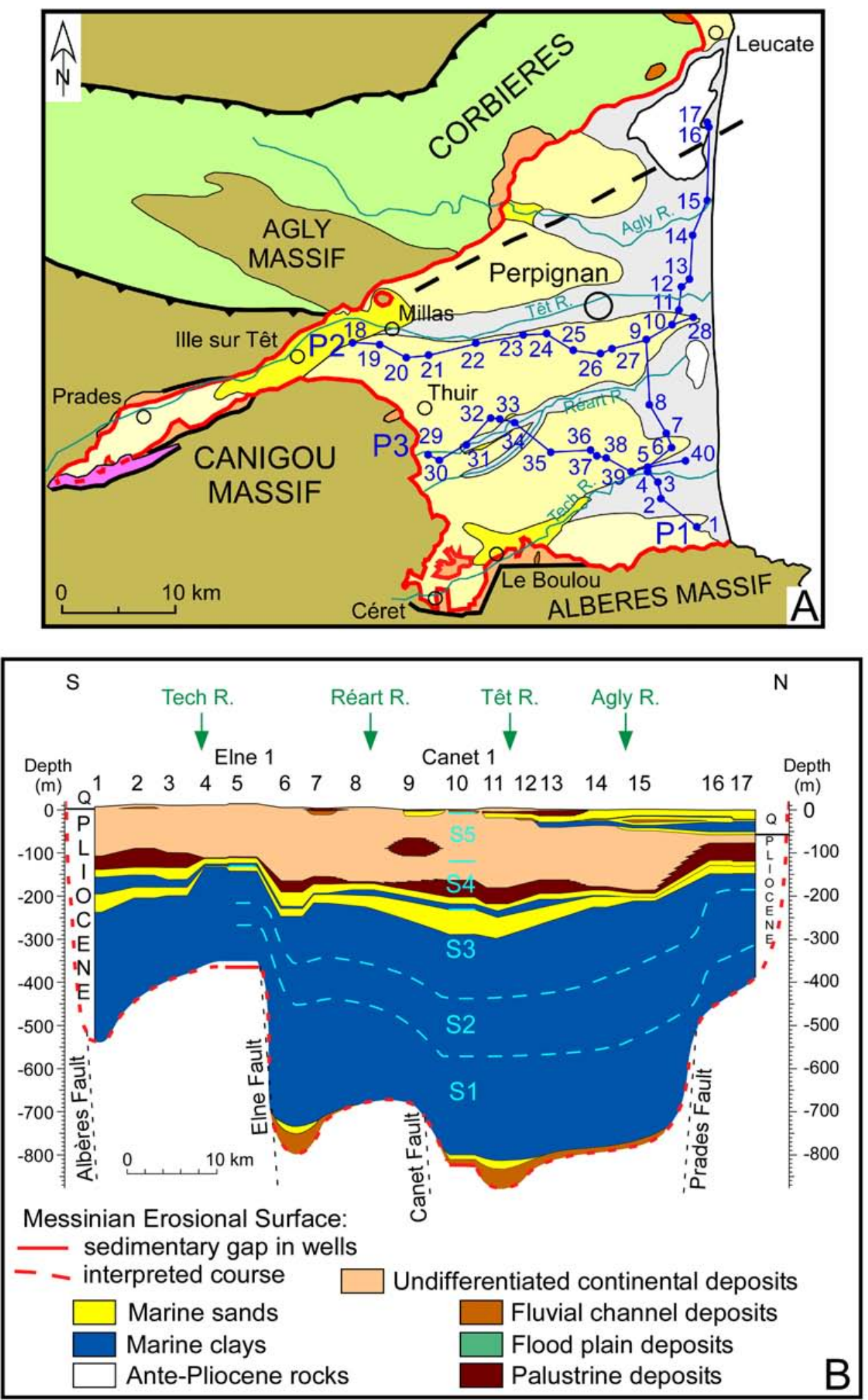

Fig. 4. Geological transects of well sections across the Roussillon Basin.

A, Map showing the location of the three transects (P1, P2, P3).

Well numbers refer to Table 1 .

$\mathrm{B}$, Transverse transect P1. Correlations of wells according to detailed logs and loggings (gamma ray and resistivity) are from Duvail (2008). Logs and loggings can be consulted on the website: http://infoterre.brgm.fr.

S1 to S5, Sedimentary sequences (separated by dotted light blue lines); Q, Quaternary. 

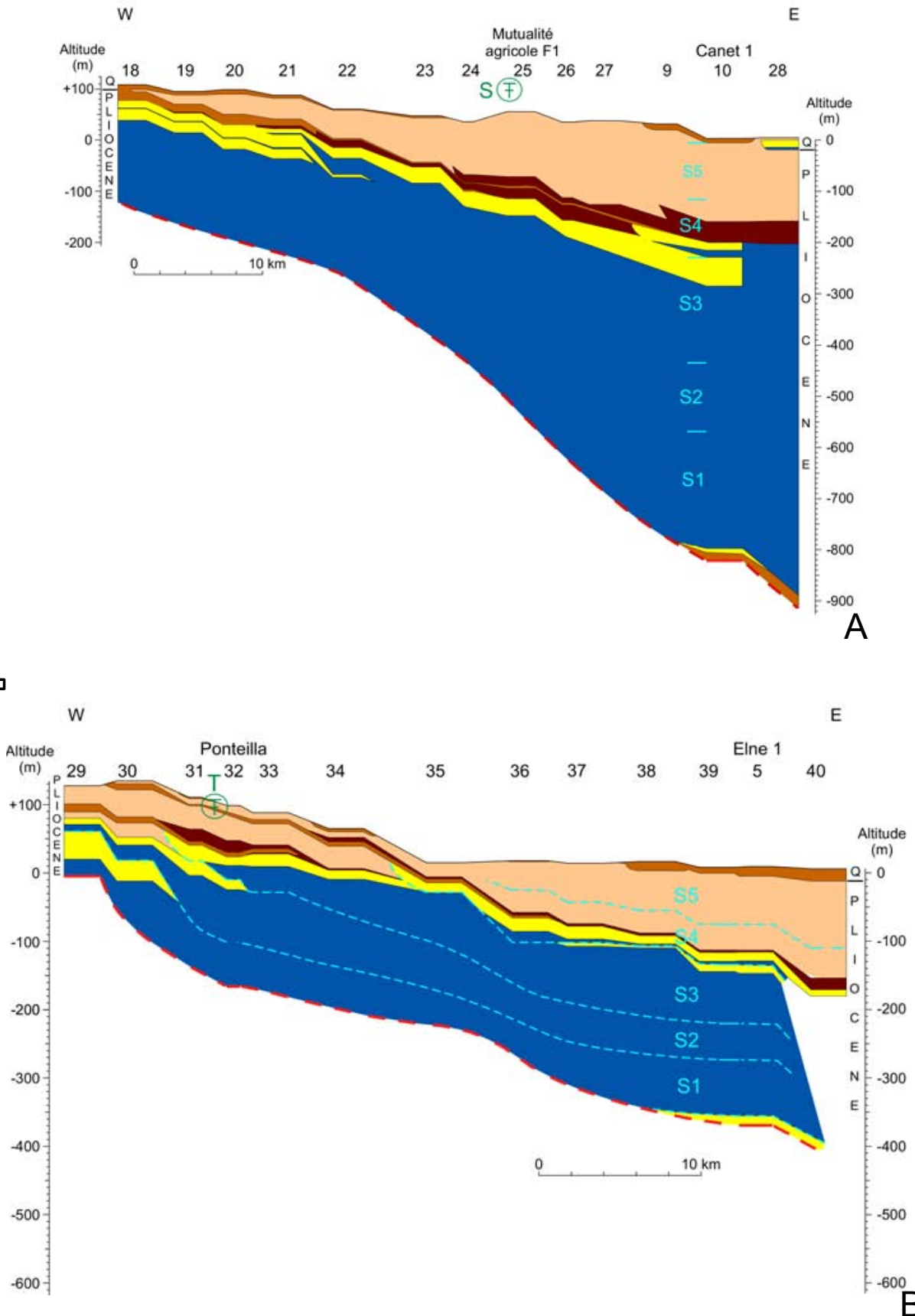

Fig. 5. Geological transects of well sections across the Roussillon Basin (continued). Correlations of wells according to detailed logs and loggings (gamma ray and resistivity) are from Duvail (2008). Logs and loggings can be consulted on the website: http://infoterre.brgm.fr. Same legend and same explanations as for Figure 4.

A, Longitudinal transect P2.

$\mathrm{S}$, Location of the Serrat d'en Vacquer mammal fauna.

$\mathrm{B}$, Longitudinal transect P3.

$\mathrm{T}$, Location of the Terrats (La Jasse) mammal fauna. 


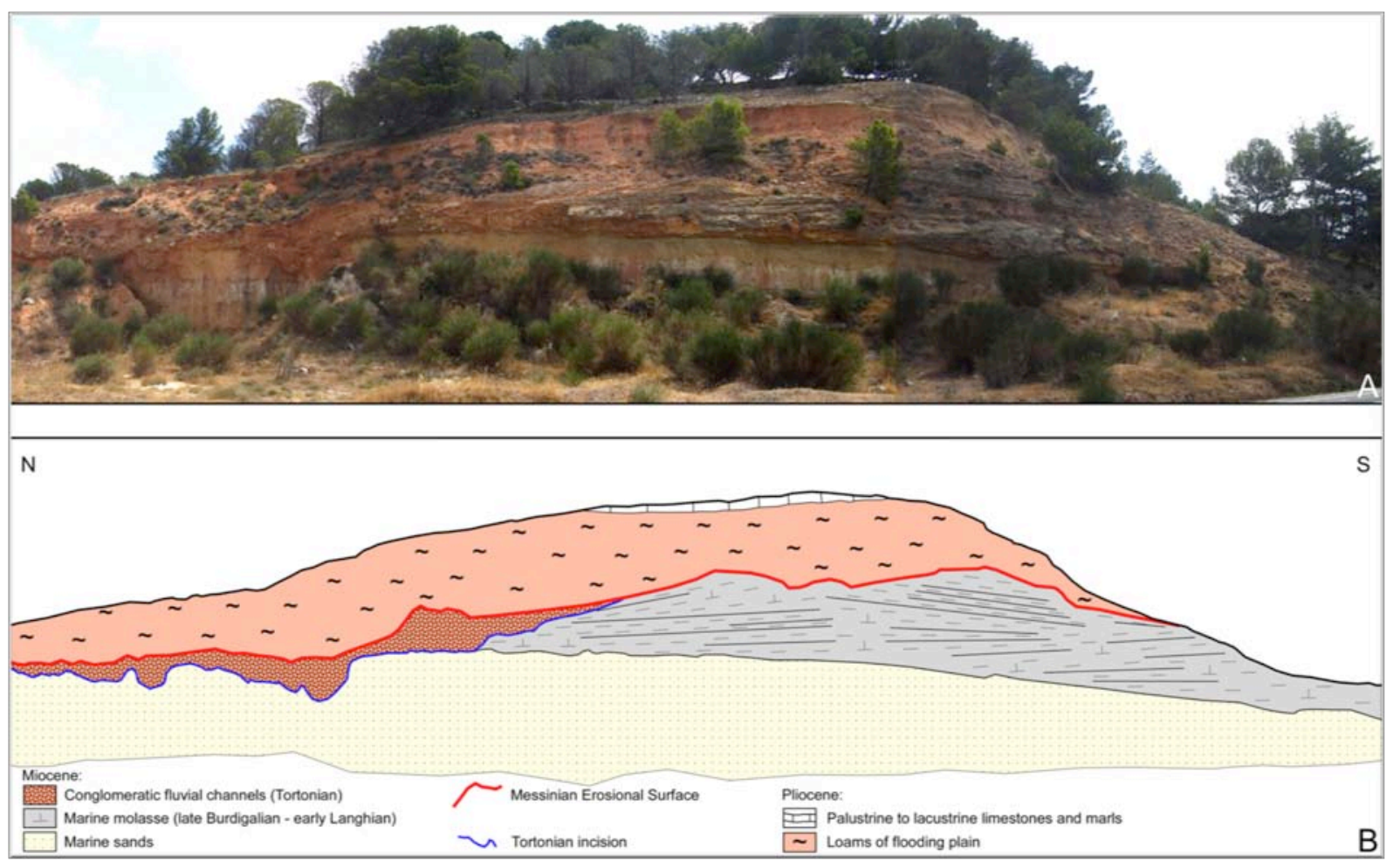

Fig. 6. The Codequas section near Leucate.

A, Panoramic photograph of the section.

$\mathrm{B}$, Its geological interpretation. 


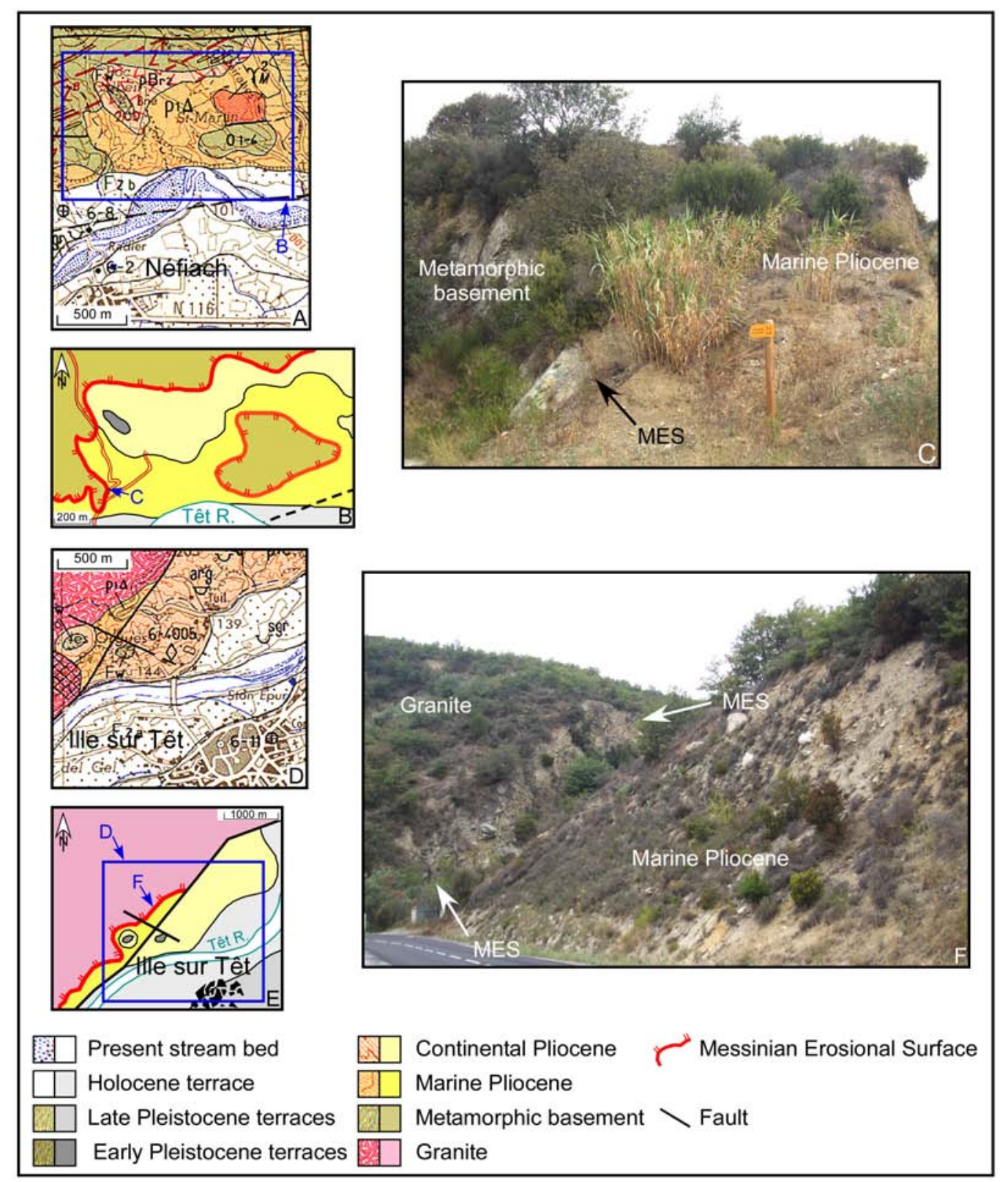

Fig. 7. The Messinian Erosional Surface in the area of Néfiach - Ille sur Têt.

A, Part of the geological map of Rivesaltes (Berger et al., 1993) showing the location of the map detailed in Figure B.

B, Detail of the geological map published by Clauzon (1990) and Clauzon et al. (1990) showing the location of the photograph in Figure C.

C, View of the Messinian Erosional Surface at Poc Calbeil (Néfiach).

D, Part of the geological map of Rivesaltes (Berger et al., 1993).

E, Detail of the geological map published by Clauzon (1990) and Clauzon et al. (1990) showing the area covered by Figure D and the location of the photograph in Figure F.

F, View of the Messinian Erosional Surface at Les Orgues (Ille sur Têt).

Of the two symbols in the legend: the left one concerns the Rivesaltes B.R.G.M. map (Figs. A and D), the right one concerns the Clauzon's maps (Figs. B and E). 


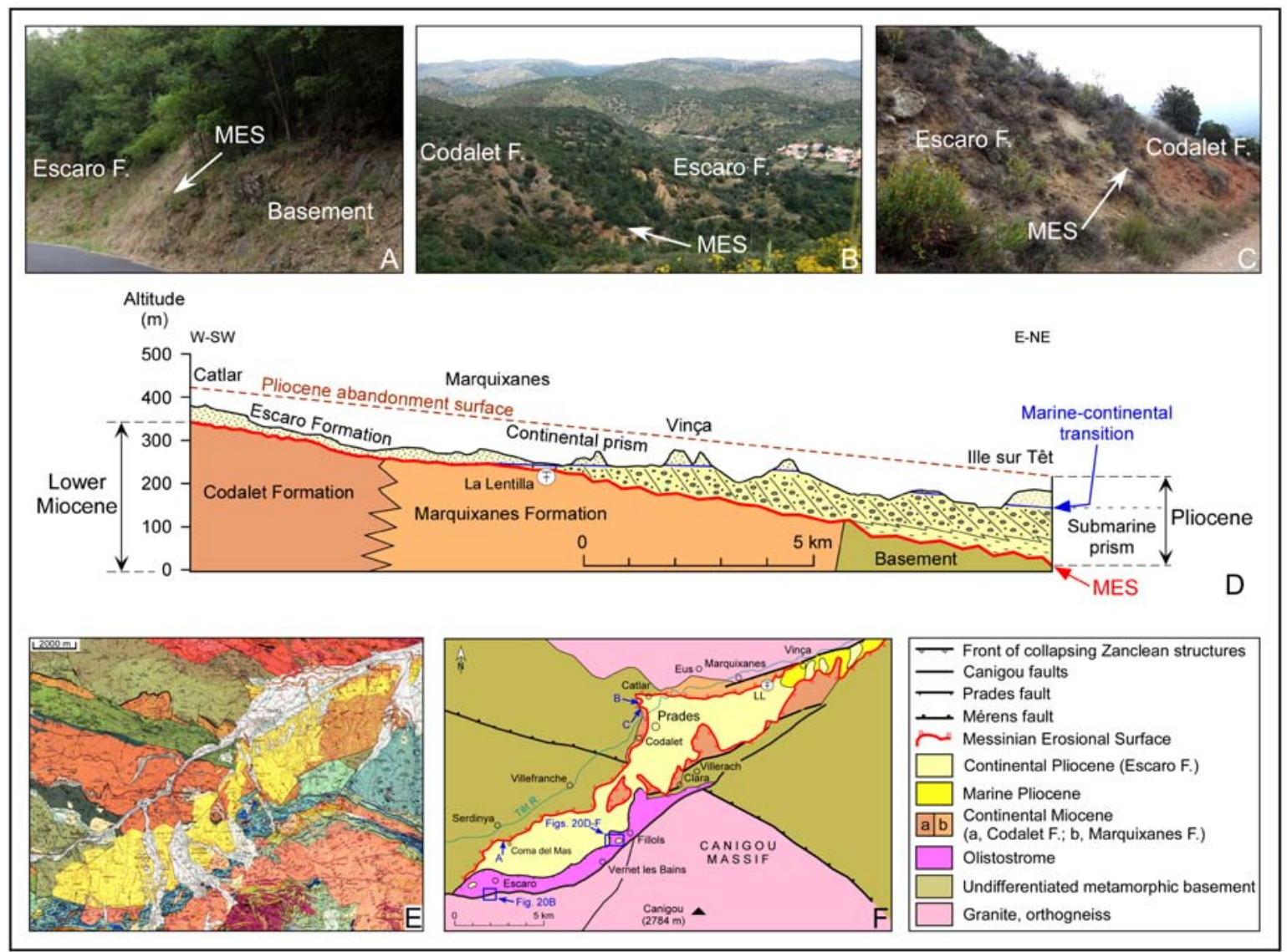

Fig. 8. The Messinian Erosional Surface in the area of Prades (Conflent territory).

A, View of the Messinian Erosional Surface at Coma del Mas (Serdinya), locality A in Fig. F.

B, View of the Messinian Erosional Surface at Montcamill (Catlar), locality B in Fig. F.

C, View of the Messinian Erosional Surface at Montcamill (Catlar), locality C in Fig. F.

D, W-SW - E-NE cross-section from Catlar to Ille sur Têt.

E, Part of the geological map of Prades (Guitard et al., 1998). The color codes are explained in the legend of the map.

F, The authors' geological map of the Conflent. A, Coma del Mas (Serdinya); B and C, Montcamill (Catlar); LL, Location of mammal fauna at La Lentilla; the blue rectangle shows the location of Figure 19.

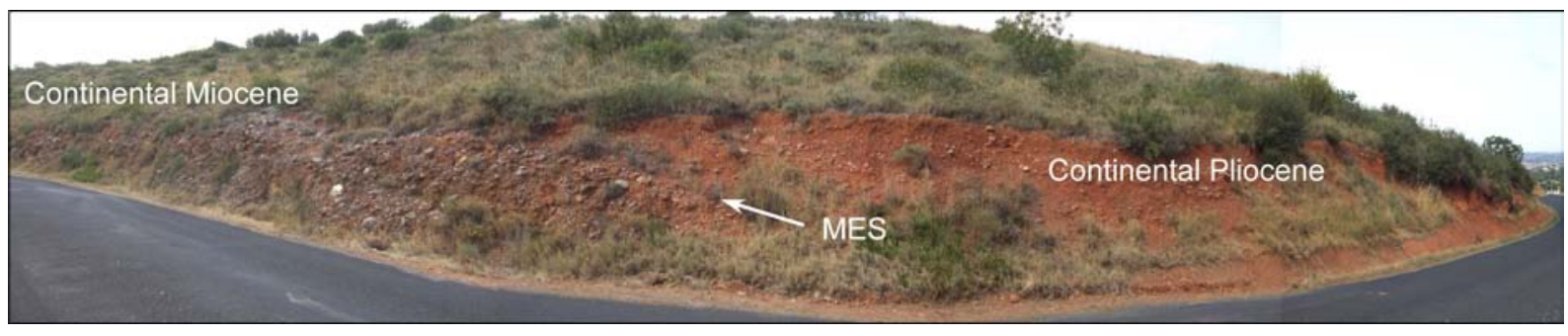

Fig. 9. Photograph of the Messinian Erosional Surface that affected the Thuir Breccia at Rigall. 


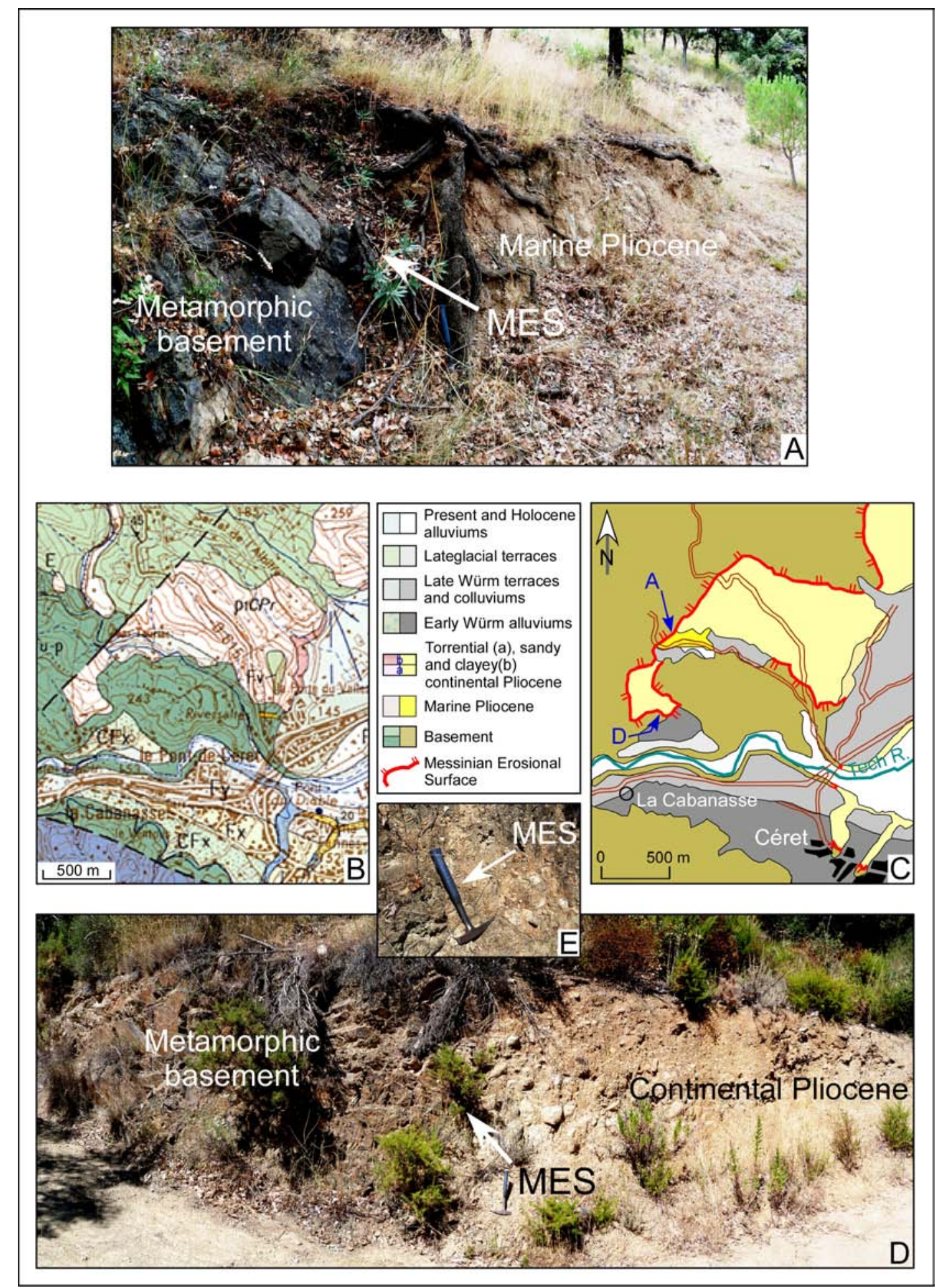

Fig. 10. The Messinian Erosional Surface in the area of Céret.

A, View of the Messinian Erosional Surface at Mas Tauriac.

B, Part of the Céret geological map (http://www.infoterre.fr: map 1096).

C, Detail of our geological map showing the location of the photograph shown in Figures A and D.

D, View of the Messinian Erosional Surface at the Sant Pau chapel.

E, Detail of the MES at the Sant Pau chapel.

Of the two symbols in the legend: the left one concerns the Céret B.R.G.M. map (Fig. B), the right concerns the authors' map (Fig. C). 


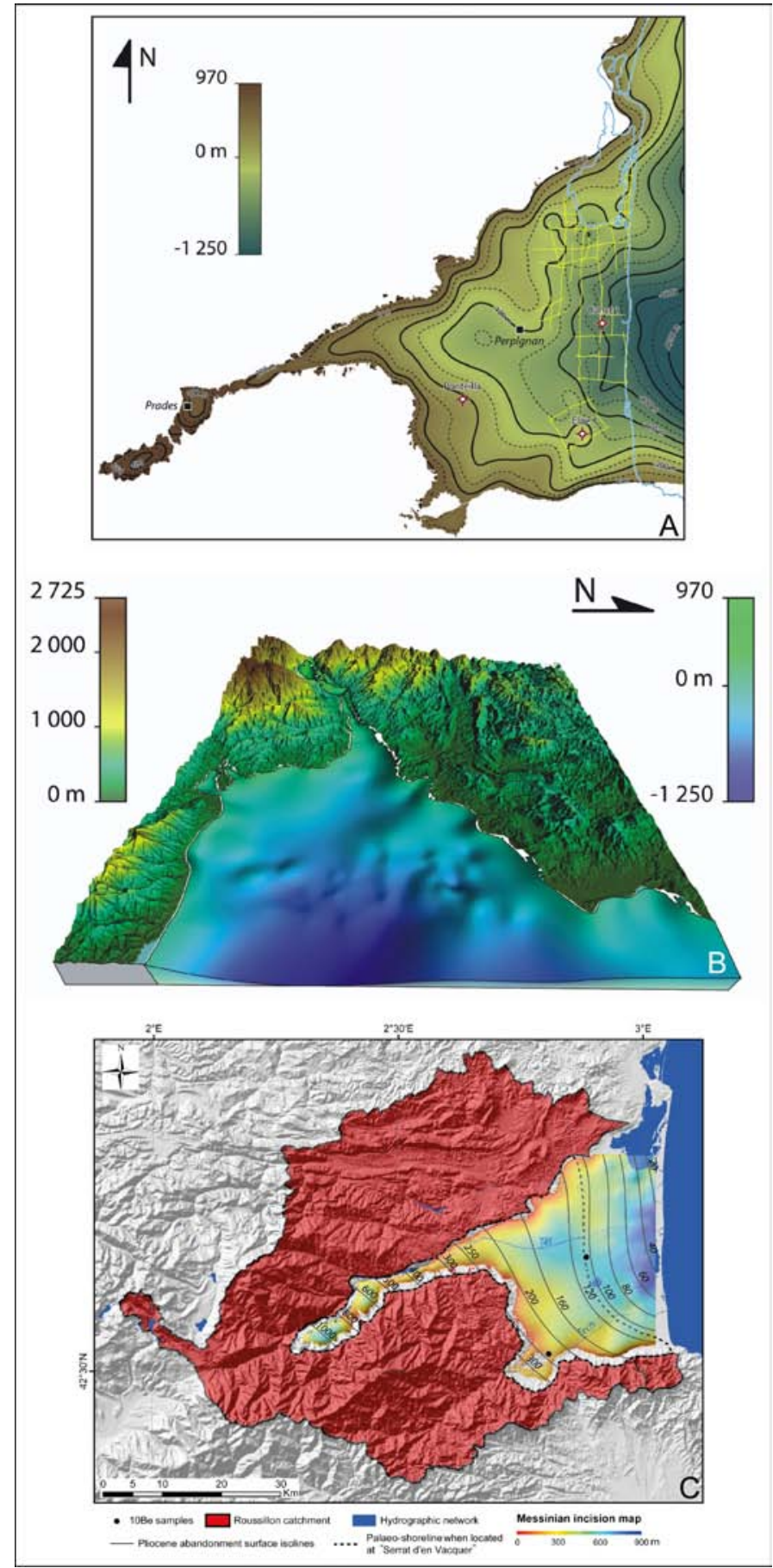

Fig. 11. Reconstructed key surfaces in the Roussillon Basin.

A, Current depth map (above and below sea level) of the MES in the Roussillon basin. The seismic lines used for the modeling process are drawn in yellow. The map also shows the locations of the three mains wells.

$\mathrm{B}$, Three-dimensional representation of the MES in the Roussillon Basin showing the two main eastward fluvial incisions.

C, Map of the reconstructed Pliocene abandonment surface over the Messinian incision map in its hydrologic setting.

The red area corresponds to the catchment feeding the Pliocene rias. The black dots show the location of the $10 \mathrm{Be}$ samples used to estimate the Pliocene denudation rate. The solid black lines are isolines corresponding to the reconstructed elevation of the Pliocene post-filling surface. The dashed line shows the expected location of the palaeo-shoreline when it was located at "Serrat d'en Vacquer". 


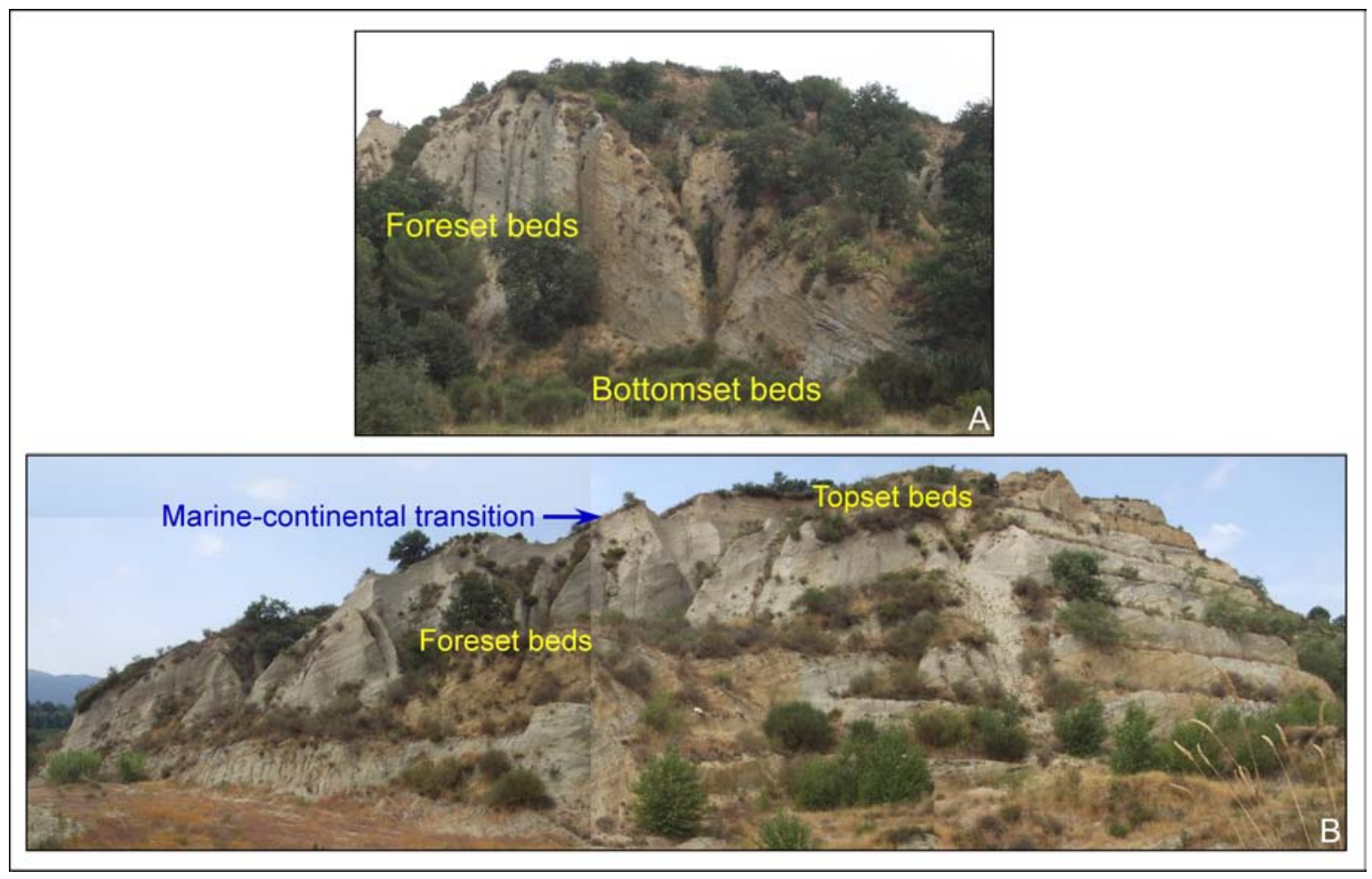

Fig. 12. Gilbert-type fan delta of Bente Farine (Néfiach), lateral to the Têt River axis.

A, Distal view of its western side.

$\mathrm{B}$, Proximal view of its eastern side.

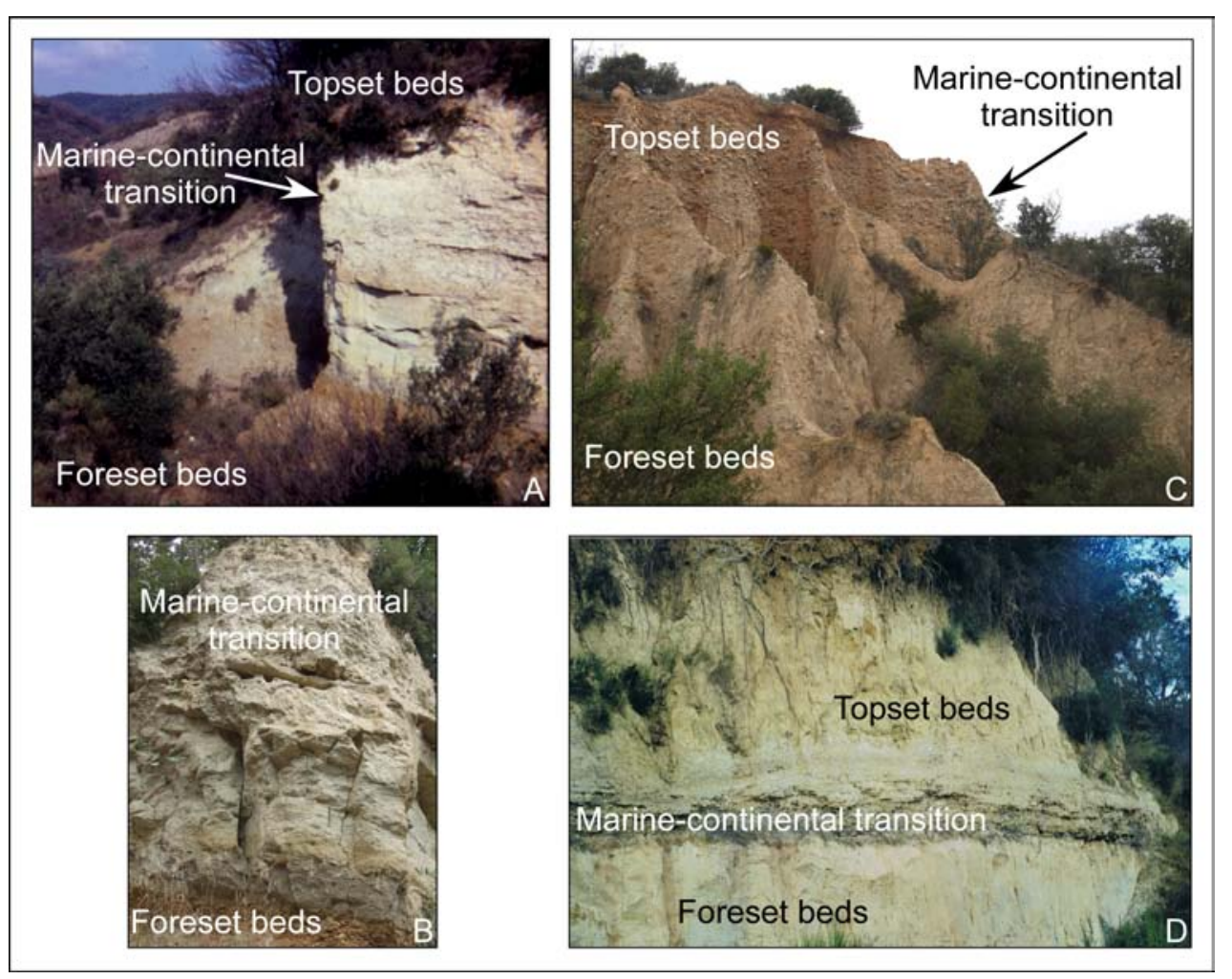

Fig. 13. Examples of the marine-continental transition observed within the Zanclean Gilbert-type fan deltas near the MES.
A, Poc Calbeil (Néfiach).
B, Detail at Poc Calbeil (Néfiach).
C, Les Escoumes (Vinça).
$\mathrm{D}$, Els Pontells (Vivès). 


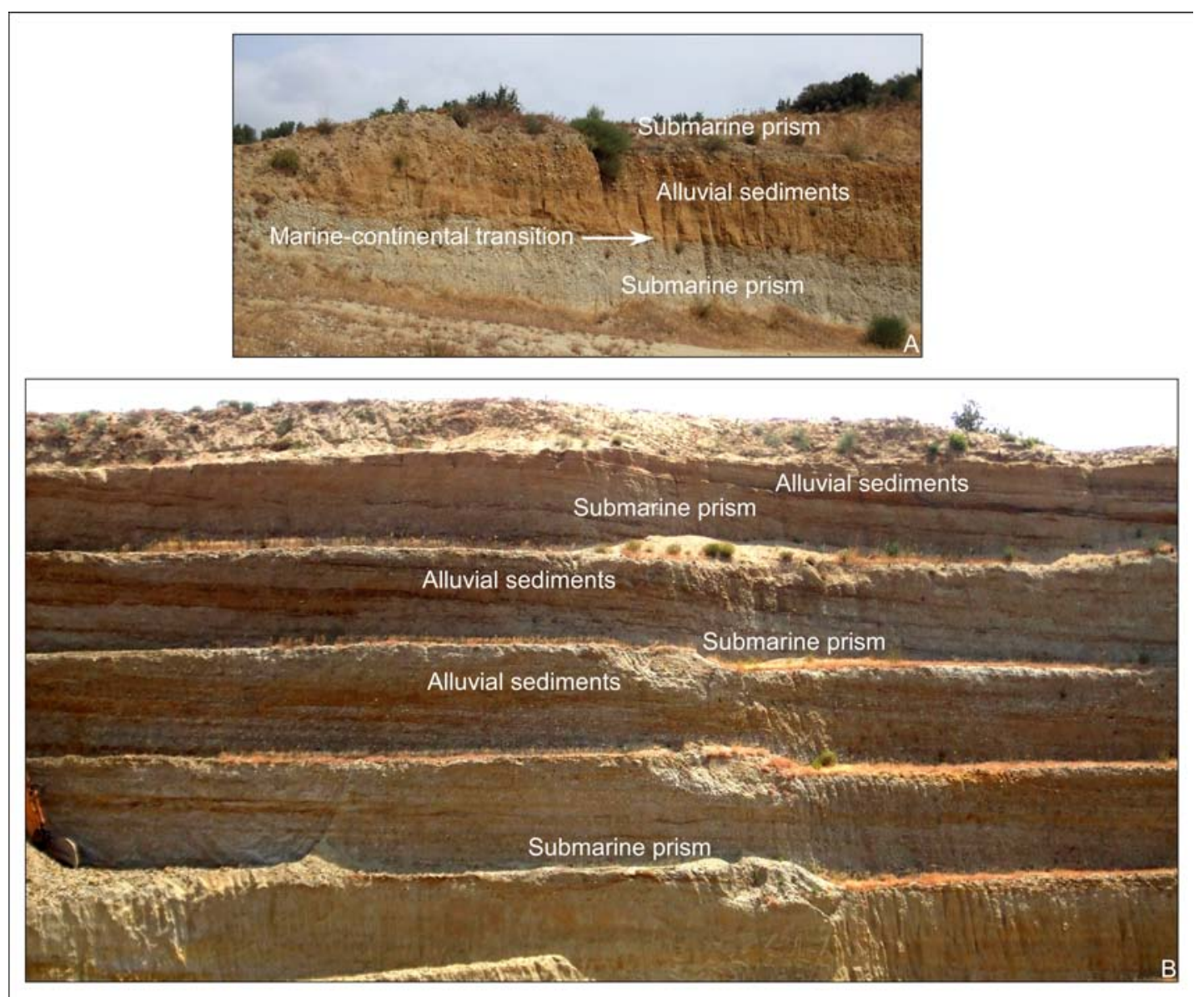

Fig. 14. Sedimentary prisms at Bente Farine (Néfiach).
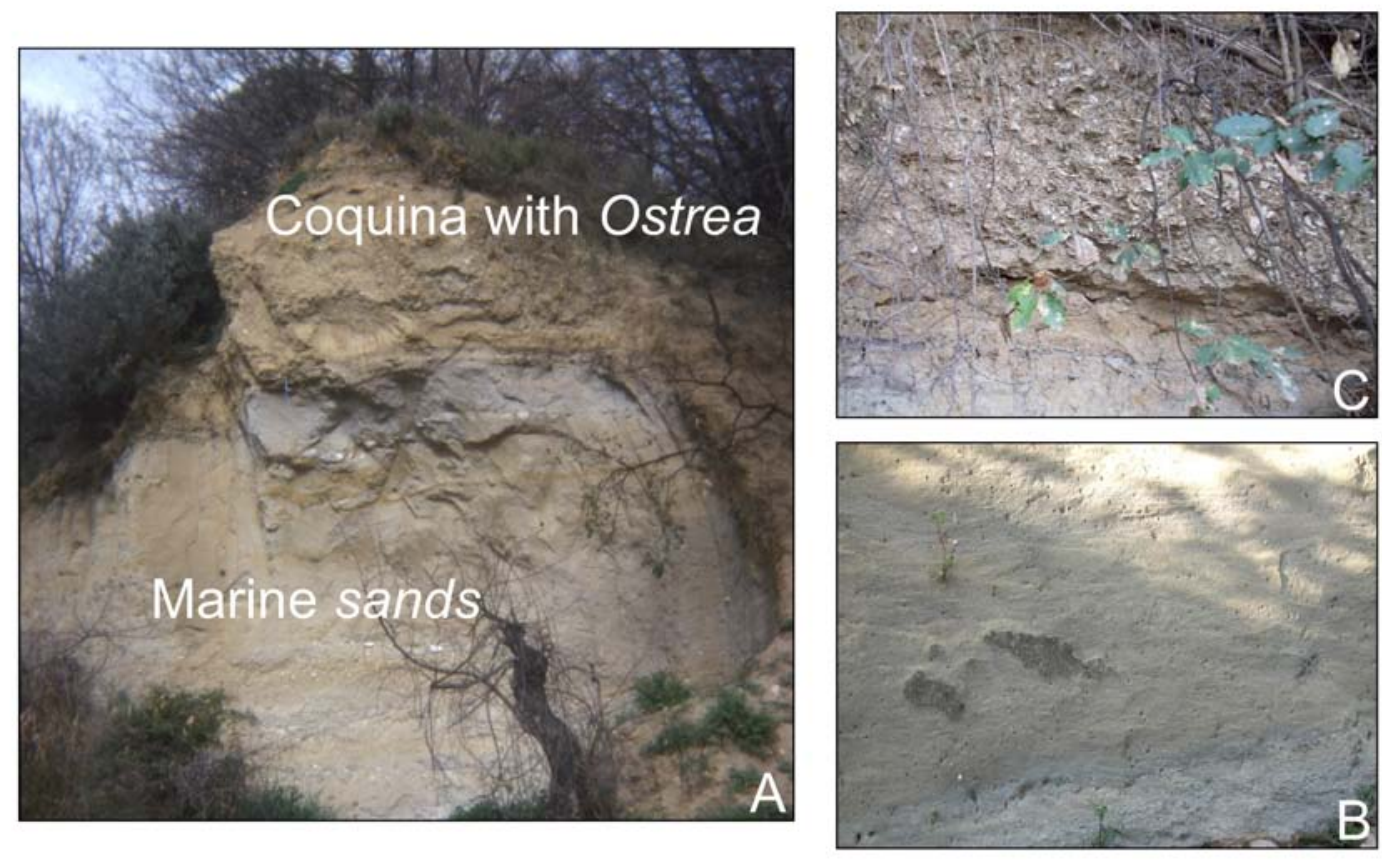

Fig. 15. The Ribèral section at Trouillas.

A, Complete view of the section.

B, Marine sands with tide ripple marks.

C, Coquina with Ostrea cucullata. 


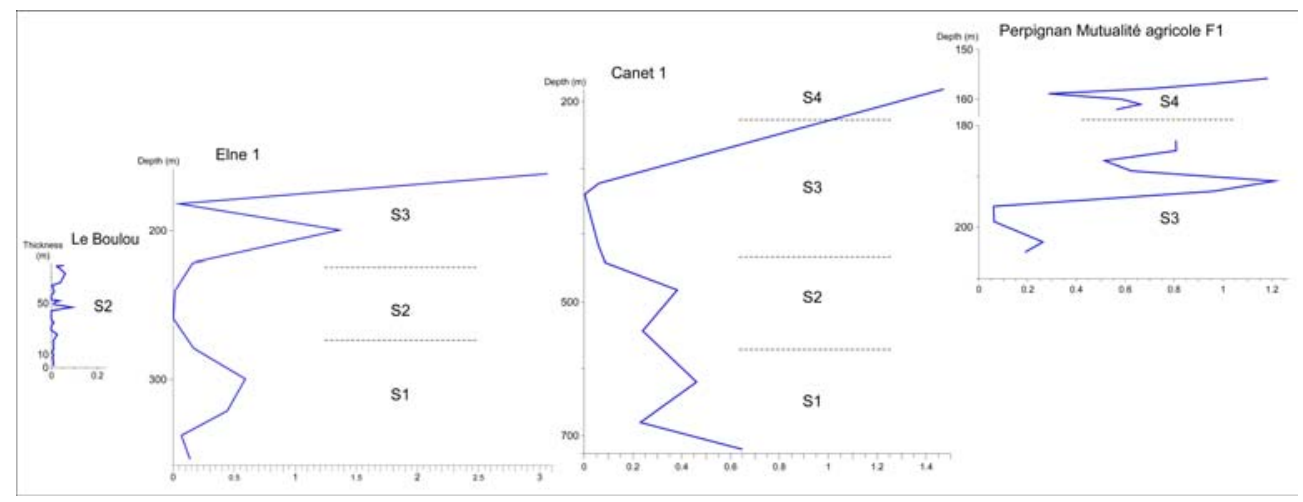

Fig. 16. Comparison of the "Halophytes / Pinus" pollen ratio in the long sections Le Boulou, Elne 1, Canet 1 and Mutualité agricole F1.

S1 to S4, Sedimentary sequences located in Figures 4B and 5.

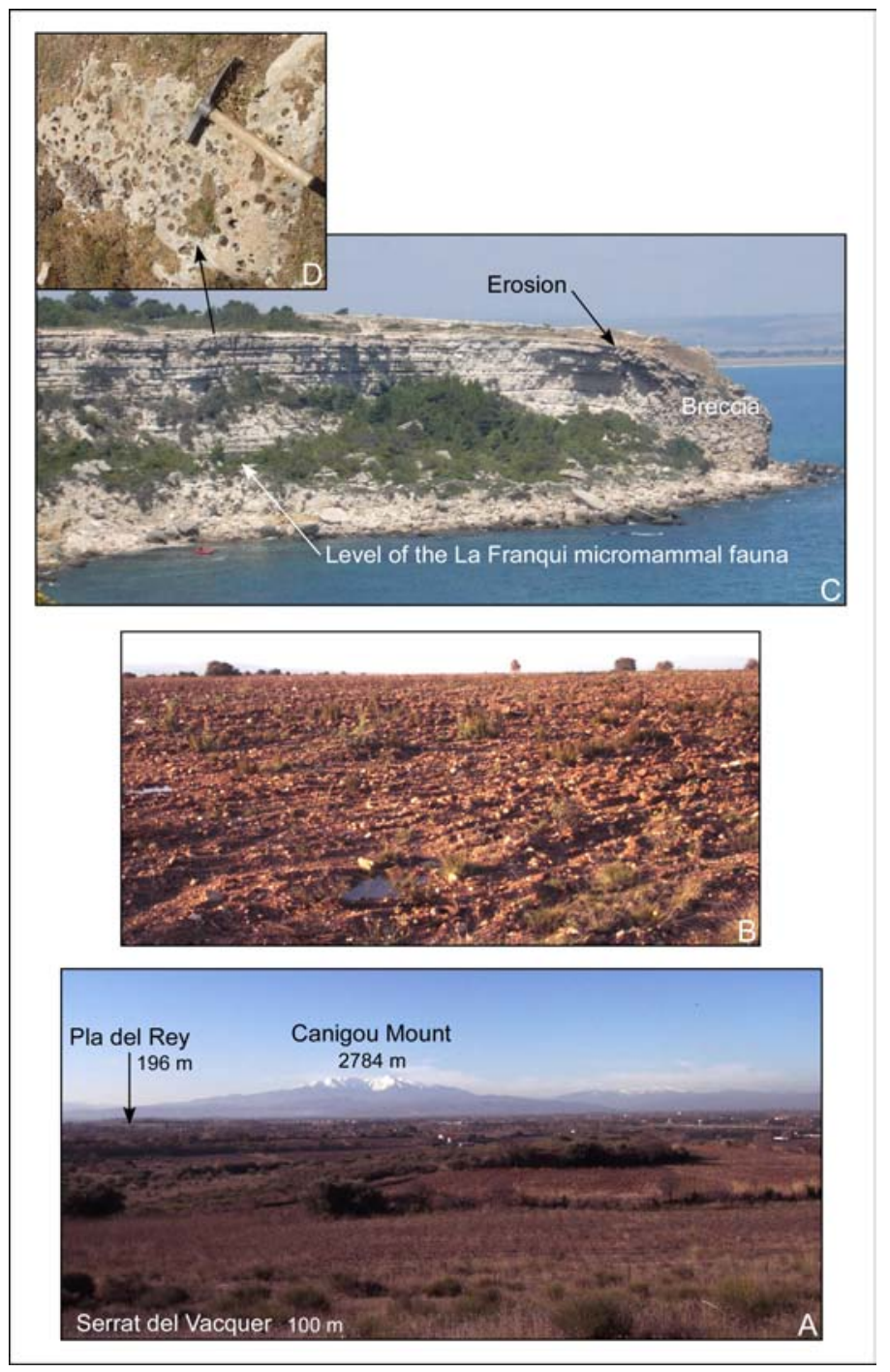

Fig. 17. The surface topping the Roussillon Pliocene sedimentary filling.

A, B, In its alluvial expression at Pla del Rey (Tresserre): A, View from the Serrat d'en Vacquer; B, Surface with siliceous pebbles and its red alteration (196 m asl).

C, D, In its coastal expression at Trois Frères Cape (La Franqui): C, La Franqui section and the top surface (60 m asl) cut by Late Pliocene erosion; $\mathrm{D}$, Burrows cut by saxicavous mollusks in the surface. 


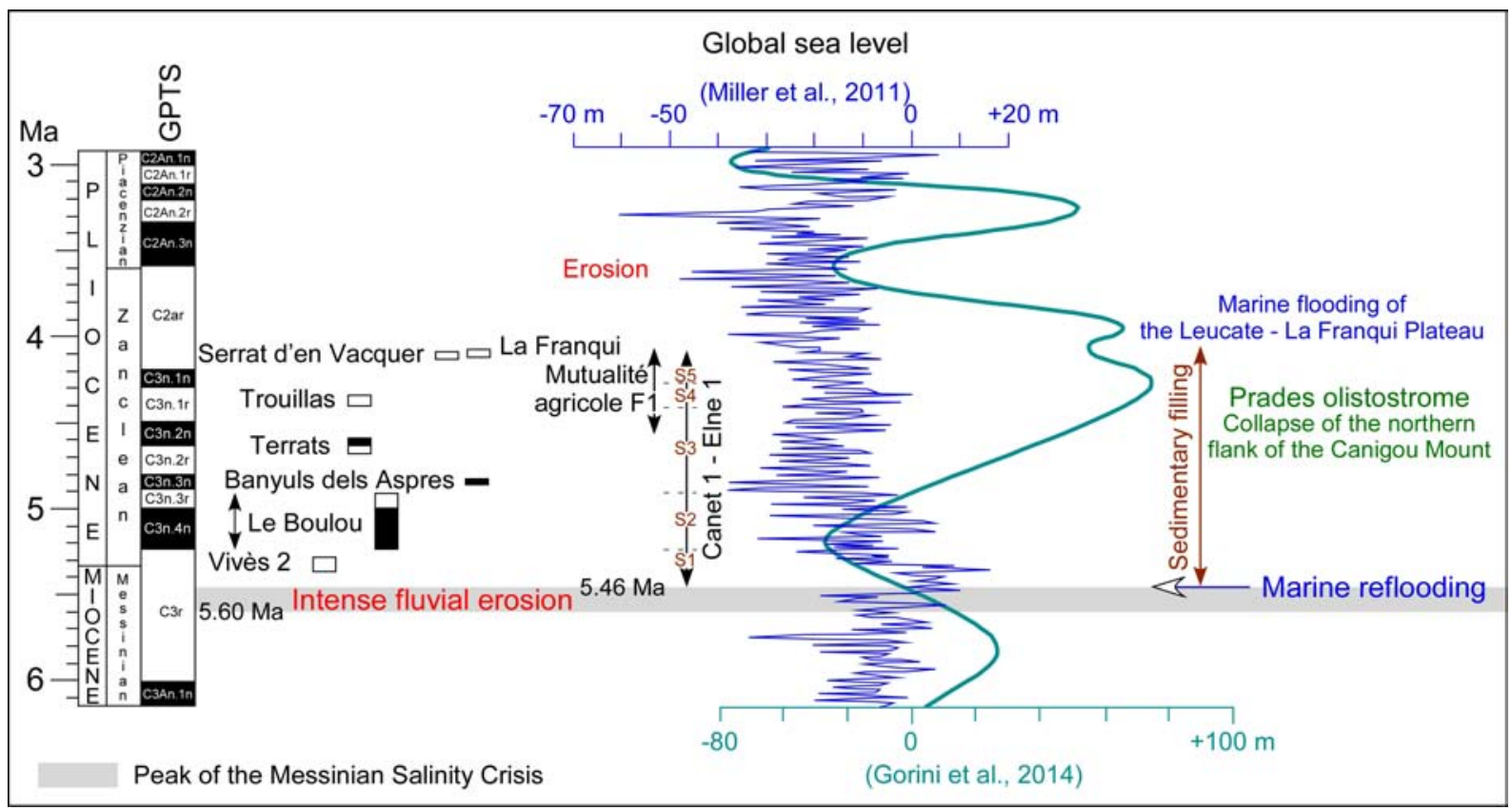

Fig. 18. Chronostratigraphy of the events that affected the Roussillon Basin during the time interval 6-3 Ma, with respect to global changes in sea level. GPTS, Global Polarity Time Scale from Lourens et al. (2005).

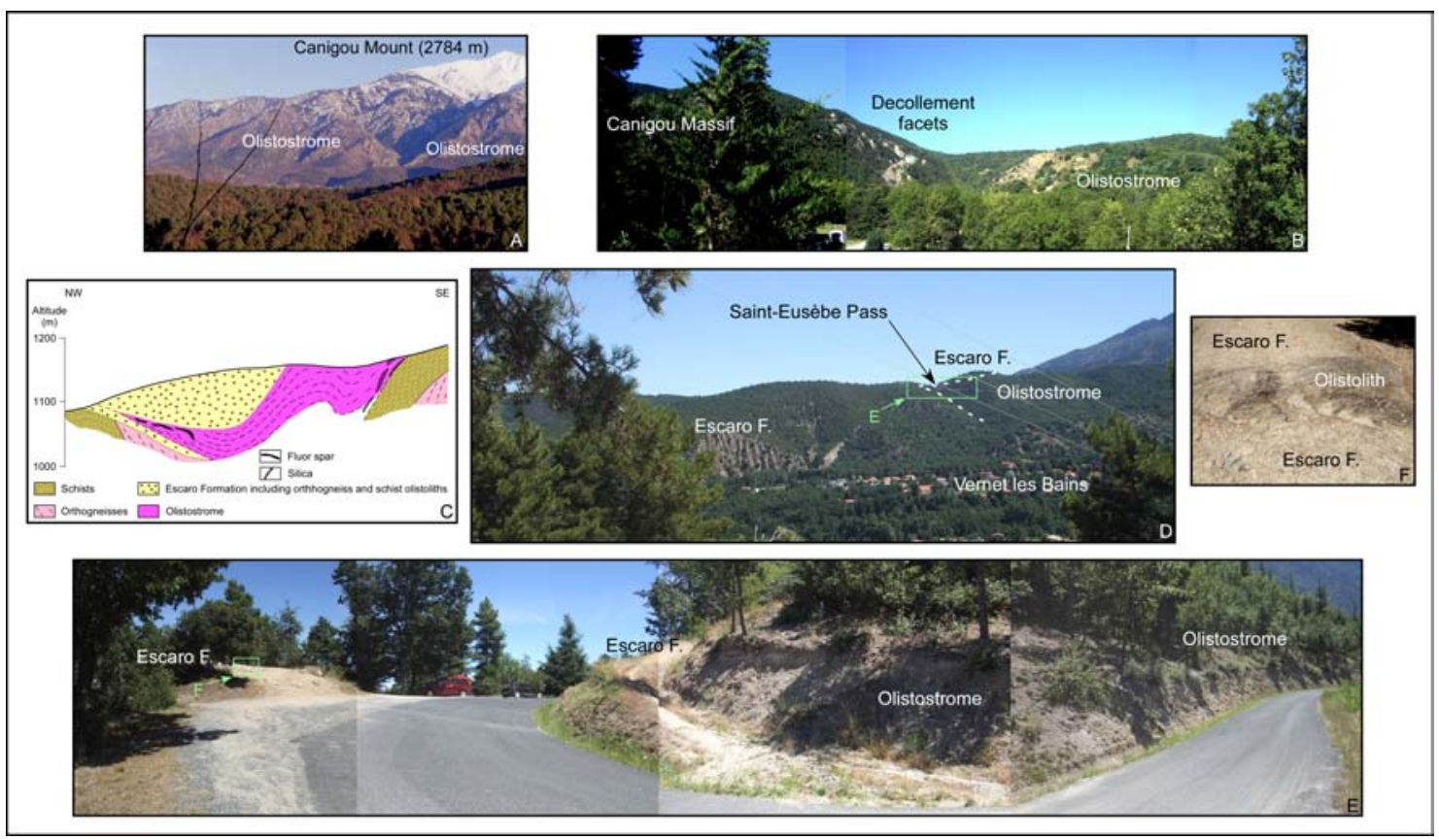

Fig. 19. The Prades olistostrome.

A, Overview of the olistostrome on the northern flank of the Canigou Massif. B, At Escaro, contact between the olistostrome and the Canigou orthogneisses marked by decollement facets.

C, Section across the olistostrome, from Huard and Pelissonnier (1969).

D, Overview of the Prades olistostrome sandwiched inside the Escaro Formation at the Saint-Eusèbe pass.

E, Detail of the contact between the olistostrome and the Escaro Formation at the Saint-Eusèbe pass.

F, At the Saint-Eusèbe pass, a block from the olistostrome incorporated within the sediments of the Escaro Formation. 


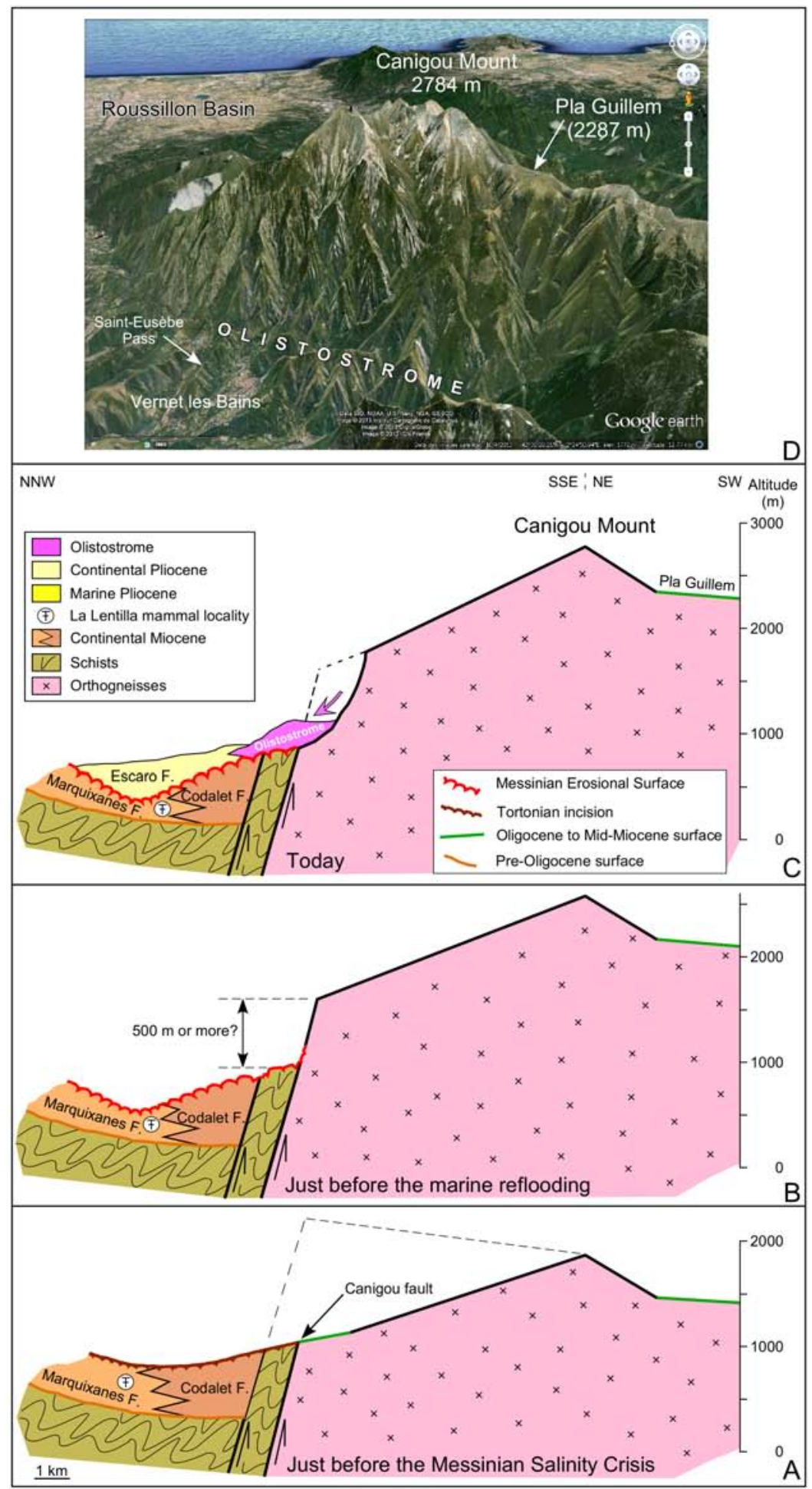

Fig. 20. Evolution of the northern flank of the Canigou Massif since 6 Ma.

A, Before the Messinian Salinity Crisis. The palaeoaltitude is estimated.

B, After the peak of the Messinian Salinity Crisis, just before the marine reflooding of the Mediterranean basin but just after reactivation of the Canigou fault.

C, Present-day relationships among the units and geometries, particularly with regard to the Prades olistostrome.

D, Three-dimensional Google earth view of the Canigou Massif from its northern flank, with location of the Prades olistostrome and the uplifted Oligocene-Miocene surface (Pla Guillem). Elevation is three times exaggerated. 


\begin{tabular}{|c|c|c|c|c|c|}
\hline Well $n^{\circ}$ & Name & Latitude $\mathbf{N}$ & Longitude E & Altitude (m) & Depth (m) \\
\hline 1 & 1097-6X-0002 & $42^{\circ} 33^{\prime} 1^{\prime \prime}$ & $3^{\circ} 1^{\prime} 23^{\prime \prime}$ & 9 & 401.970 \\
\hline 2 & $1097-2 X-0135$ & $42^{\circ} 34^{\prime} 16^{\prime \prime}$ & $2^{\circ} 59^{\prime} 16^{\prime \prime}$ & 14 & 144 \\
\hline 3 & $1097-2 X-0137$ & $42^{\circ} 35^{\prime} 2^{\prime \prime}$ & $2^{\circ} 59^{\prime} 7^{\prime \prime}$ & 14.54 & 166 \\
\hline 4 & $1097-2 X-0138$ & $42^{\circ} 35^{\prime} 31^{\prime \prime}$ & $2^{\circ} 58^{\prime} 30^{\prime \prime}$ & 13 & 157 \\
\hline 5 & $\begin{array}{l}\text { 1097-2X-037 } \\
\text { Elne } 1\end{array}$ & $42^{\circ} 35^{\prime} 38^{\prime \prime}$ & $2^{\circ} 58^{\prime} 32^{\prime \prime}$ & 14.50 & 2275.60 \\
\hline 6 & $1097-2 X-0145$ & $42^{\circ} 36^{\prime} 31^{\prime \prime}$ & $2^{\circ} 59^{\prime} 53^{\prime \prime}$ & 7 & 220 \\
\hline 7 & $1097-2 X-0088$ & $42^{\circ} 38^{\prime} 27^{\prime \prime}$ & 3'1'8" & 2.46 & 252 \\
\hline 8 & 1097-2X-0161 & $42^{\circ} 37^{\prime} 28^{\prime \prime}$ & $2^{\circ} 57^{\prime} 19^{\prime \prime}$ & 10 & 50 \\
\hline 9 & $1091-6 X-0013$ & $42^{\circ} 40^{\prime} 20^{\prime \prime}$ & $2^{\circ} 59^{\prime} 15^{\prime \prime}$ & 2 & 149 \\
\hline 10 & $\begin{array}{l}\text { 1091-6X-007 } \\
\text { Canet } 1\end{array}$ & $42^{\circ} 42^{\prime} 55^{\prime \prime}$ & $3^{\circ} 0^{\prime} 2^{\prime \prime}$ & 3.72 & 1837.20 \\
\hline 11 & 1091-6X-0018 & $42^{\circ} 42^{\prime} 29^{\prime \prime}$ & $3^{\circ} 0^{\prime} 27^{\prime \prime}$ & 7 & 202 \\
\hline 12 & 1091-6X-0015 & $42^{\circ} 43^{\prime} 31^{\prime \prime}$ & $3^{\circ} 0^{\prime} 38^{\prime \prime}$ & 5 & 150 \\
\hline 13 & 1091-6X-0073 & $42^{\circ} 43^{\prime} 53^{\prime \prime}$ & 31'3" & 3 & 205 \\
\hline 14 & $1091-2 X-0110$ & $42^{\circ} 45^{\prime} 48^{\prime \prime}$ & 3०1'19" & 2.56 & 235 \\
\hline 15 & $1091-2 X-0111$ & $42^{\circ} 47^{\prime} 17^{\prime \prime}$ & $3^{\circ} 2^{\prime} 16^{\prime \prime}$ & 3.43 & 210 \\
\hline 16 & 1079-6X-0066 & $42^{\circ} 50^{\prime} 36^{\prime \prime}$ & $3^{\circ} 2 ' 12^{\prime \prime}$ & 1 & 170 \\
\hline 17 & $1079-6 X-0056$ & $42^{\circ} 50^{\prime} 32^{\prime \prime}$ & $3^{\circ} 2 ' 21^{\prime \prime}$ & 1.64 & 301 \\
\hline 18 & 1090-6X-028 & $42^{\circ} 41^{\prime} 10^{\prime \prime}$ & $2^{\circ} 41^{\prime} 4^{\prime \prime}$ & 108 & 74 \\
\hline 19 & 1090-7X-131 & $42^{\circ} 41^{\prime} 4^{\prime \prime}$ & $2^{\circ} 42^{\prime} 43^{\prime \prime}$ & 100 & 175 \\
\hline 20 & $1090-7 X-0024$ & $42^{\circ} 40^{\prime} 29^{\prime \prime}$ & $2^{\circ} 44^{\prime} 14^{\prime \prime}$ & 98 & 155 \\
\hline 21 & $1090-7 X-0051$ & $42^{\circ} 40^{\prime} 37^{\prime \prime}$ & $2^{\circ} 45^{\prime} 34^{\prime \prime}$ & 87 & 141 \\
\hline 22 & $1090-8 X-0071$ & $42^{\circ} 41^{\prime} 6 "$ & $2^{\circ} 48^{\prime} 19^{\prime \prime}$ & 72 & 150 \\
\hline 23 & $1090-8 X-0251$ & $42^{\circ} 41^{\prime} 27^{\prime \prime}$ & 251'14" & 47 & 115 \\
\hline 24 & 1090-8X-0011 & $42^{\circ} 41^{\prime} 29^{\prime \prime}$ & $2^{\circ} 52^{\prime} 33^{\prime \prime}$ & 35 & 146.5 \\
\hline 25 & $\begin{array}{l}1091-5 X-0270 \\
\text { Mutualité agricole } \\
\text { F1 }\end{array}$ & $42^{\circ} 40^{\prime} 20.89^{\prime \prime}$ & $2^{\circ} 52^{\prime} 59.99 "$ & 70 & 206 \\
\hline 26 & 1091-5X-0002 & $42^{\circ} 40^{\prime} 41^{\prime \prime}$ & $2^{\circ} 55^{\prime} 43^{\prime \prime}$ & 35 & 199 \\
\hline 27 & $1091-5 X-333$ & $42^{\circ} 40^{\prime} 50^{\prime \prime}$ & $2^{\circ} 57^{\prime} 5^{\prime \prime}$ & 39 & 122 \\
\hline 28 & 1091-6X-074 & $42^{\circ} 42^{\prime} 13^{\prime \prime}$ & $3^{\circ} 1 ' 23^{\prime \prime}$ & 4 & 200 \\
\hline 29 & $1096-3 X-0054$ & $42^{\circ} 36^{\prime} 13^{\prime \prime}$ & $2^{\circ} 45^{\prime} 31^{\prime \prime}$ & 127 & 108 \\
\hline 30 & $1096-3 X-0014$ & $42^{\circ} 36^{\prime} 33^{\prime \prime}$ & $2^{\circ} 45^{\prime} 7^{\prime \prime}$ & 136 & 170 \\
\hline 31 & $1096-4 X-0008$ & $42^{\circ} 36^{\prime} 43^{\prime \prime}$ & $2^{\circ} 47^{\prime} 45^{\prime \prime}$ & 110.96 & 150 \\
\hline 32 & $\begin{array}{l}\text { 1096-4X-0017 } \\
\text { Ponteilla }\end{array}$ & $42^{\circ} 37^{\prime} 25^{\prime \prime}$ & $2^{\circ} 48^{\prime} 38^{\prime \prime}$ & 100 & 719.40 \\
\hline 33 & $1096-6 X-0077$ & $42^{\circ} 37^{\prime} 30^{\prime \prime}$ & $2^{\circ} 48^{\prime} 59^{\prime \prime}$ & 89 & 177 \\
\hline 34 & 1096-4X-0119 & $42^{\circ} 37^{\prime} 44^{\prime \prime}$ & $2^{\circ} 50^{\prime} 38^{\prime \prime}$ & 69.37 & 97 \\
\hline 35 & $1097-1 X-0194$ & $42^{\circ} 36^{\prime} 18^{\prime \prime}$ & $2^{\circ} 52^{\prime} 47^{\prime \prime}$ & 15 & 75 \\
\hline 36 & $1097-1 X-0126$ & $42^{\circ} 36^{\prime} 11^{\prime \prime}$ & $2^{\circ} 55^{\prime} 29^{\prime \prime}$ & 16.16 & 153 \\
\hline 37 & $1097-1 X-0124$ & $42^{\circ} 36^{\prime} 3^{\prime \prime}$ & $2^{\circ} 56^{\prime} 1^{\prime \prime}$ & 15.33 & 153 \\
\hline 38 & $1097-1 X-0120$ & $42^{\circ} 35^{\prime} 27^{\prime \prime}$ & $2^{\circ} 57^{\prime} 30^{\prime \prime}$ & 17 & 128 \\
\hline 39 & $1097-2 X-0138$ & $42^{\circ} 35^{\prime} 31^{\prime \prime}$ & $2^{\circ} 58^{\prime} 30^{\prime \prime}$ & 13 & 150 \\
\hline 40 & $1097-2 X-0136$ & $42^{\circ} 35^{\prime} 57^{\prime \prime}$ & $3^{\circ} 0^{\prime} 46^{\prime \prime}$ & 6.06 & 193 \\
\hline
\end{tabular}

Table 1. Information on the wells used in Figures 4 and 5. 


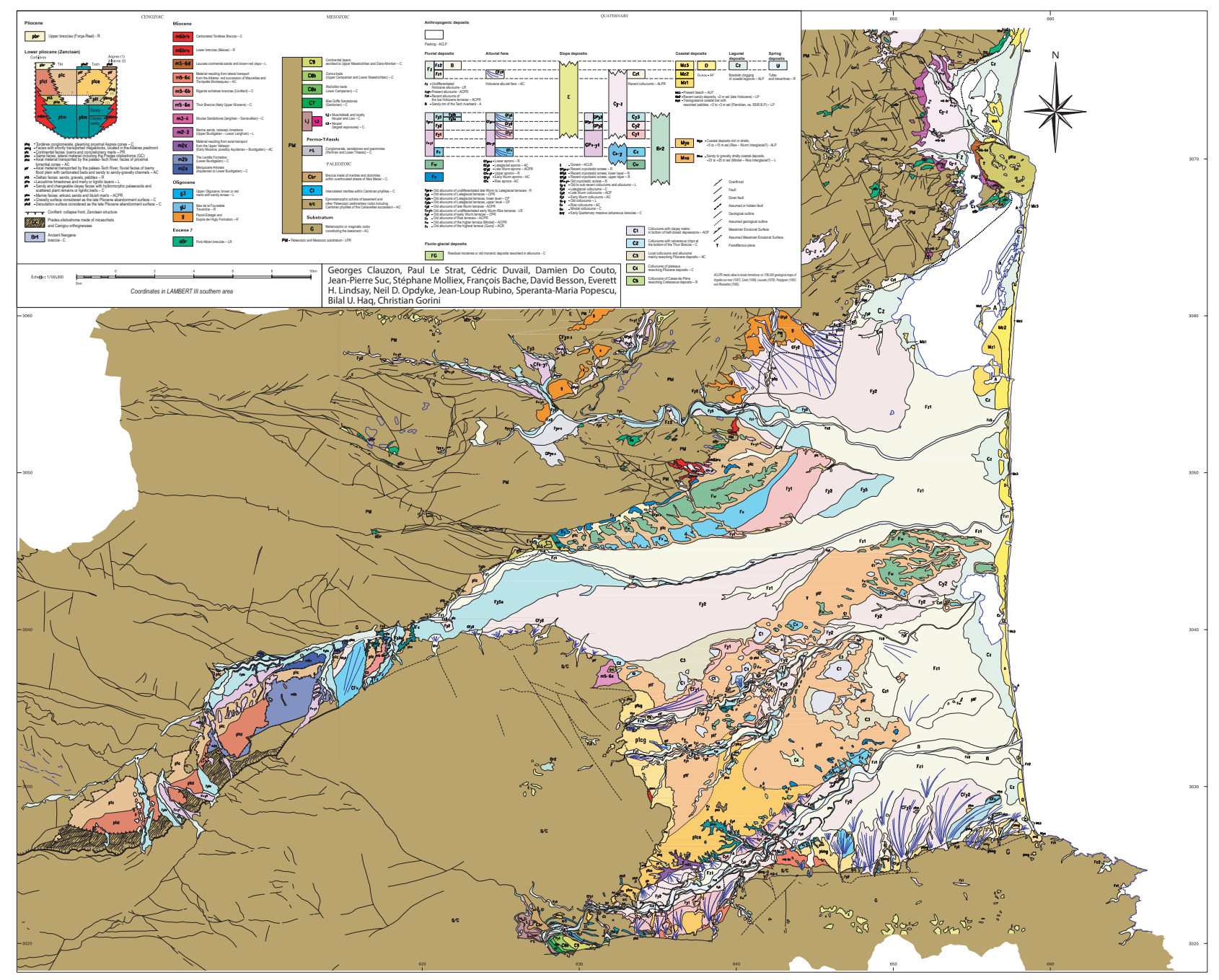

Suppl. data 1.

Geological map at scale 1/100,000 of Cenozoic deposits of the Roussillon Basin. 
The chemical treatment of the samples and the AMS measurements were carried out at the Laboratoire National des Nucléides Cosmogéniques (LN2C) in the Centre Européen de Recherche et d'Enseignement des Géosciences de l'Environnement (CEREGE), Aix-enProvence. Samples were prepared for ${ }^{10} \mathrm{Be}$ concentration measurements following chemical procedures of Brown et al. (1991) and Merchel and Herpers (1999). Pure quartz was obtained from the $500-1000 \mu \mathrm{m}$ sand fraction by repeated $\mathrm{H}_{2} \mathrm{SiF}_{6}-\mathrm{HCl}$ etching. Atmospheric ${ }^{10} \mathrm{Be}$ was subsequently eliminated by sequential dissolutions with diluted HF. $\sim 100 \mu \mathrm{l}$ of an in-house $3 \times 10^{-3} \mathrm{~g} \mathrm{~g}^{-1}{ }^{9} \mathrm{Be}$ carrier solution, prepared from deep-mined phenakite (Merchel et al., 2008), was added to each sample, and residual grains were dissolved in a strong HF solution. After the obtained solutions were evaporated to dryness and the residues were dissolved in hydrochloric acid, Be was separated by anion and cation exchange columns. After reduction of the solution volumes by heating, the Be hydroxides precipitated using $\mathrm{NH}_{3 \mathrm{aq}}$ were dried and finally ignited at $900^{\circ} \mathrm{C}$ to $\mathrm{BeO}$. $\mathrm{BeO}$ targets were prepared for measurement at the French National Accelerator Mass Spectrometry facility (ASTER), in CEREGE, Aix-enProvence. The obtained ${ }^{10} \mathrm{Be} /{ }^{9} \mathrm{Be}$ ratios were corrected for procedural blanks and calibrated against the National Institute of Standards and Technology standard reference material 4325 by using an assigned value of $2.79 \pm 0.03 \times 10^{-11}$ and a ${ }^{10} \mathrm{Be}$ half-life of $1.387 \pm 0.012 \times 10^{6}$ years (Korschinek et al., 2010; Chmeleff et al., 2010). Analytical uncertainties (reported as $1 \sigma$ ) include uncertainties associated with AMS counting statistics, chemical blank measurements and AMS internal error $(0.5 \%)$. Long-term AMS measurements of procedural blanks yield a background ratio of $3.0 \pm 1.5 \times 10^{-15}$ for ${ }^{10} \mathrm{Be} /{ }^{9} \mathrm{Be}$ (Arnold et al., 2010). A sea-level, high-latitude (SLHL) spallation production of 4.03 \pm 0.18 at g $^{-1} \mathrm{yr}^{-1}$ was used and scaled for latitude (Stone, 2000) and elevation. This production rate, recently used by Molliex et al., (2013) in the same area is based from weighted mean of the most recently calibrated production rates in the Northern Hemisphere (Northeastern North America (Balco et al., 2009), Northern Norway (Fenton et al., 2011), Southern Norway (Goehring et al., 2012) and Greenland (Briner et al., 2012). The production rate is calculated for each cells of the present-day DEM constituting the catchment and the mean catchment production rate value is calculated by averaging the values of quartz-producing rocks areas following the method described by Delunel et al., (2010) and using the script of Balco (2001) for the calculation of the shielding factor. We assumed that the mean production rate is constant through time since the Pliocene. The contribution of muons to the production rate was calculated using the physical parameters recently re-evaluated by Braucher et al. (2011). The concentrations obtained are then corrected deducing the ${ }^{10} \mathrm{Be}$ atoms gained by post-deposit exposition and adding the ${ }^{10} \mathrm{Be}$ atoms lose by radioactive decay since deposition, in order to obtain the palaeo-concentration at deposition time.

\section{References}

Arnold, M., Merchel, S., Bourles, D.L., Braucher, R., Benedetti, L., Finkel, R.C., Aumaître, G., Gottdang, A., Klein, M., 2010. The French accelerator mass spectrometry facility ASTER: Improved performance and developments. Nucl. Instr. Methods Phys. Res. B268, 1954-1959.

Balco, G., 2001. Cosmogenic Isotope Production Rates Over Large Areas. http://depts.washington.edu/cosmolab/P by GIS.html

Balco, G., Briner, J., Finkel, R.C., Rayburn, J.A., Ridge, J.C., Schaefer, J.M., 2009. Regional beryllium-10 production rate calibration for late-glacial northeastern North America. Quat. Geo. 4, 93-107.

Braucher, R., Merchel, S., Borgomano, J., Bourlès, D.L., 2011. Production of cosmogenic radionuclides at great depth: a multi element approach. Earth Planet. Sci. Lett. 309, 1-9. 
Briner, J.P., Young, N.E., Goehring, B.M., Schaefer, J.M., 2012. Constraining Holocene 10Be production rates in Greenland. Journ. Quat. Sci. 27, 2-6.

Brown, E.T., Edmond, J.M., Raisbeck, G.M., Yiou, F., Kurz, M.D., Brook, E.J., 1991, Examination of surface exposure ages of Antarctic moraines using in situ produced ${ }^{10} \mathrm{Be}$ and ${ }^{26} \mathrm{Al}$ : Geochim. Cosmochim. Acta 55, 2269-2283.

Chmeleff, J., von Blanckenburg, F., Kossert, K., Jakob, J, 2010. Determination of the ${ }^{10} \mathrm{Be}$ half-life by multicollector ICP-MS and liquid scintillation counting. Nucl. Instr. Methods Phys. Res. B268, 192-199.

Delunel, R., van der Beek, P.A., Carcaillet, J., Bourlès, D.L., Valla, P.G., 2010. Frostcracking control on catchment denudation rates: Insights from in situ produced $10 \mathrm{Be}$ concentrations in stream sediments (Ecrins-Pelvoux massif, French Western Alps), Earth Planet. Sci. Lett. 293, 72-83.

Fenton, C.R., Hermanns, R.L., Blikra, L.H., Kubik, P.W., Bryant, C., Niedermann, S., Meixner, A., Goethals, M.M., 2011. Regional ${ }^{10}$ Be production rate calibration for the past $12 \mathrm{ka}$ deduced from the radiocarbon-dated Grotlandsura and Russenes rock avalanches at $69^{\circ} \mathrm{N}$, Norway. Quat. Geo. 6, 437-452.

Goehring, B.M., Lohne, Ø.S., Mangerud, J., Svendsen, J.I., Gyllencreutz, R., Schaefer, J.M., Finkel, R.C., 2012. Late Glacial and Holocene beryllium-10 production rates for western Norway. Journ. Quat. Sci. 27, 89-96.

Korschinek, G., Bergmaier, A., Faestermann, T., Gerstmann, U.C., Knie, K., Rugel, G.,Wallner, A., Dillmann, I., Dollinger, G., von Gostomski, Lierse Ch., Kossert, K., Maitia,M., Poutivtsev, M., Remmert, A., 2010. A new value for the half-life of ${ }^{10}$ Be by Heavy-Ion Elastic Recoil Detection and liquid scintillation counting. Nucl. Instr. Methods Phys. Res. B268, 187-191.

Merchel, S., Herpers, U., 1999. An update on radiochemical separation techniques for the determination of long-lived radionuclides via accelerator mass spectrometry. Radiochim. Acta 84, 215-219.

Merchel S., Arnold M., Aumaitre G., Benedetti L., Bourles D.L., Braucher R., Alfimov V., Freeman S.P.H.T., Steier P., Wallner A., 2008. Towards more precise ${ }^{10} \mathrm{Be}$ and ${ }^{36} \mathrm{Cl}$ data from measurements at the $10^{-14}$ level: Influence of sample preparation. Nucl. Instr. Methods Phys. Res. B266, 4921-4926.

Molliex, S., Siame, L., Bourlès, D.L., Braucher, R., Bellier, O., Clauzon, G., 2013. Quaternary evolution of a large alluvial fan in a peri-glacial setting (Crau plain, SE France), constrained by terrestrial cosmogenic nuclide (10Be). Geomorphology 195, 4552.

Stone, J.O., 2000. Air pressure and cosmogenic isotope production. Journ. Geophys. Res. 105, $23753-23759$.

Suppl. data 2.

Detailed method for cosmogenic nuclide $10 \mathrm{Be}$ chemical treatment and palaeodenudation rate interpretation. 
Suppl. Data 3.

Cosmogenic study results for Pliocene denudation rate estimation in the Roussillon rias. The ${ }^{10} \mathrm{Be}$ corrected values represent the concentration measured corrected by subtracting the post-depositional re-exposure and adding the post-depositional radioactive decay in order to obtain the palaeo-concentration at the deposition time. Production rate corresponds to an average value of production in all quartz-producing rocks located in the catchment. 